\title{
Hydrologic Data and Description of a Hydrologic Monitoring Plan for the \\ Borax Lake Area, Oregon
}

U.S. Geological Survey

Open-File Report 95-367

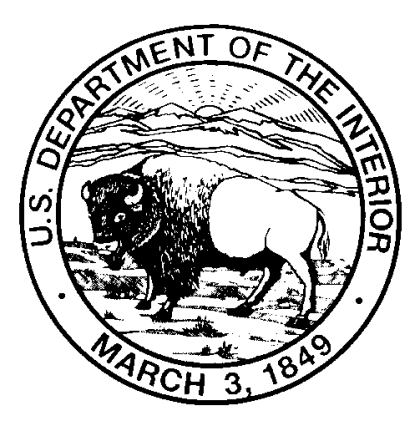




\section{Hydrologic Data and Description of a Hydrologic Monitoring Plan for the \\ Borax Lake Area, Oregon}

By TIFFANY RAE SCHNEIDER and WILLIAM D. MCFARLAND

U.S. Geological Survey

Open-File Report 95-367 


\title{
U.S. DEPARTMENT OF THE INTERIOR BRUCE BABBITT, Secretary
}

\author{
U.S. GEOLOGICAL SURVEY \\ GORDON P. EATON, Director
}

The use of trade, product, or firm names in this publication is for descriptive
purposes only and does not imply endorsement by the U.S. Government.

For additional information write to:

District Chief

U.S. Geological Survey, WRD

10615 S.E. Cherry Blossom Drive

Portland, Oregon 97216
Copies of this report can be purchased from:

U.S. Geological Survey Earth Science Information Center Open-File Reports Section Box 25286, MS 517

Denver Federal Center

Denver, CO 80225 


\section{CONTENTS}

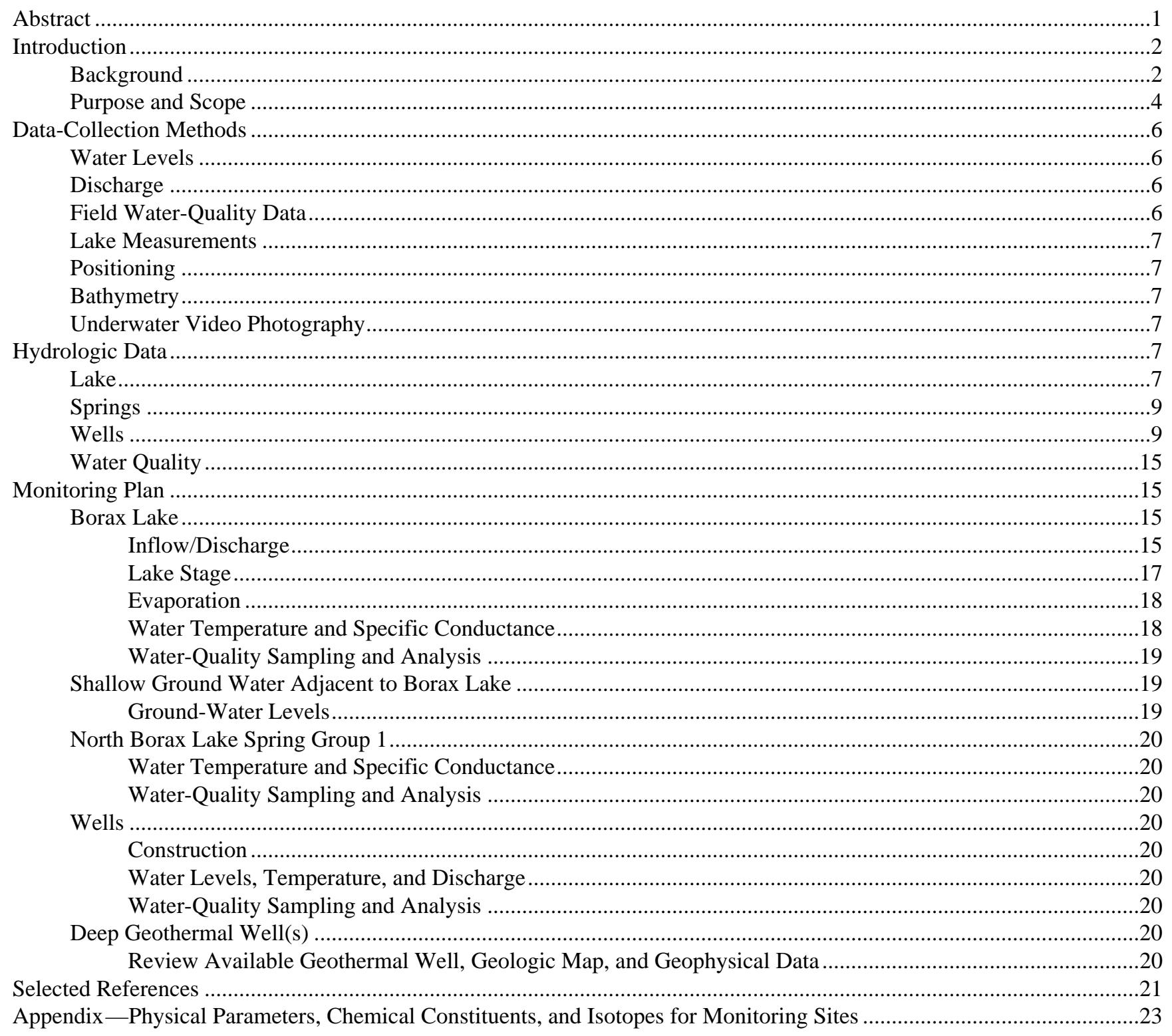




\section{FIGURES}

1-2. Maps showing:

1. Location of Borax Lake study area, Oregon 3

2. Location in Oregon of Borax Lake Spring Group, North Borax Lake Spring Group 1, and benchmarks and main vent at Borax Lake.....

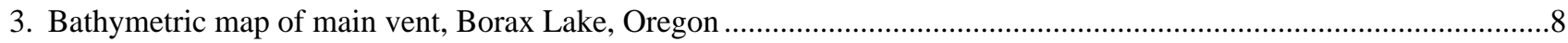

4. Map showing location of North Borax Lake Spring Group 4, Oregon..................................................................10

\section{TABLES}

1. Records of selected springs in the Pueblo Valley, Oregon

2. Records of selected wells in the Pueblo Valley, Oregon

3. Results of chemical analyses of water samples collected from the Borax Lake area, Oregon

\section{WELL-NUMBERING SYSTEM}

The well-numbering system used in this report is based on the rectangular system for subdivision of public land. Each "number" (actually number-letter designation) indicates the location of the well with respect to township, range, and section. Number 37S/34E-7bab indicates a well in T.37 S., R.34 E., sec. 7. Townships shown in this region are numbered south and east of the Willamette Baseline and Meridian (for example 37S/34E). The letters show the location within the section; the first letter (a) identifies the quarter section (160 acres); the second letter (a), identifies the quarter-quarter section (40 acres); and the third letter (c) identifies the quarter-quarter-quarter section (10 acres). Well 7 bab is in the NW quarter of the NE quarter of the NW quarter of section 7, township 37 south, range 34 east (see figure below).

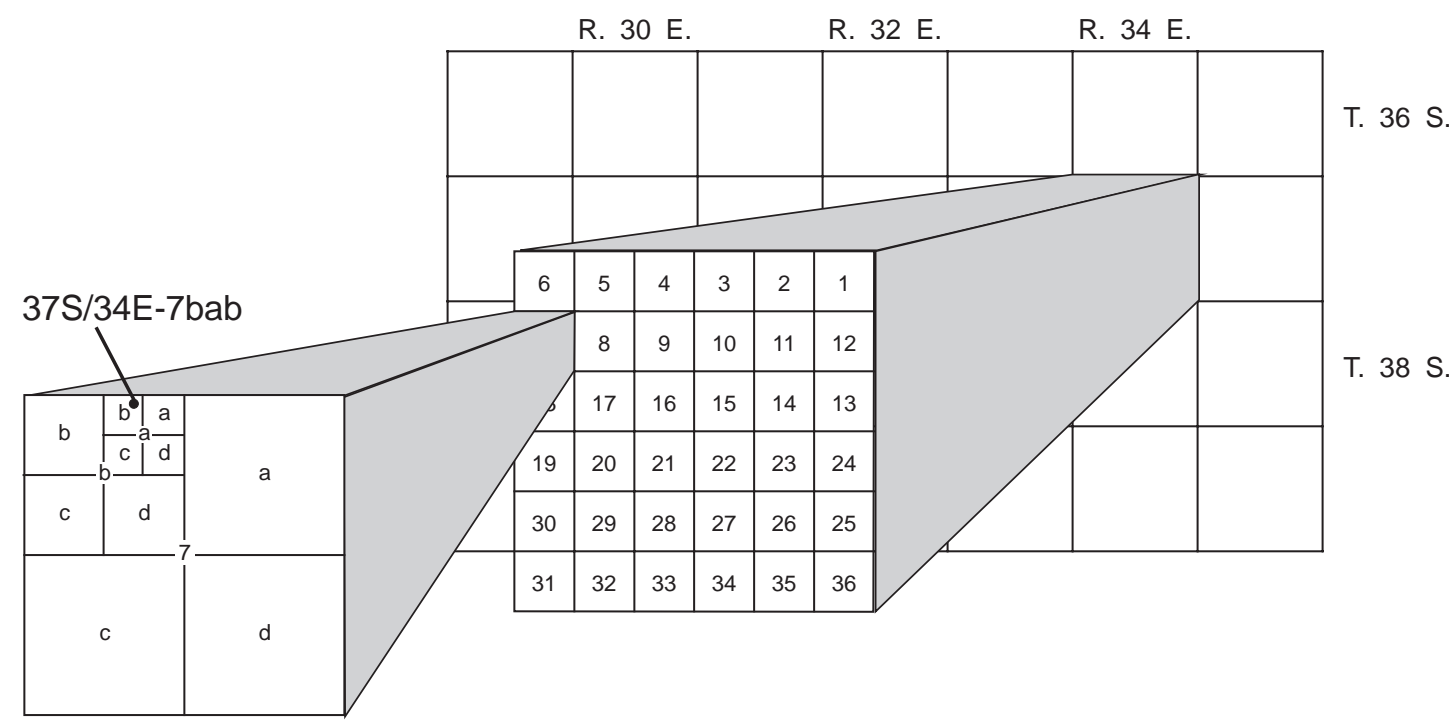




\section{CONVERSION FACTORS AND ABBREVIATIONS}

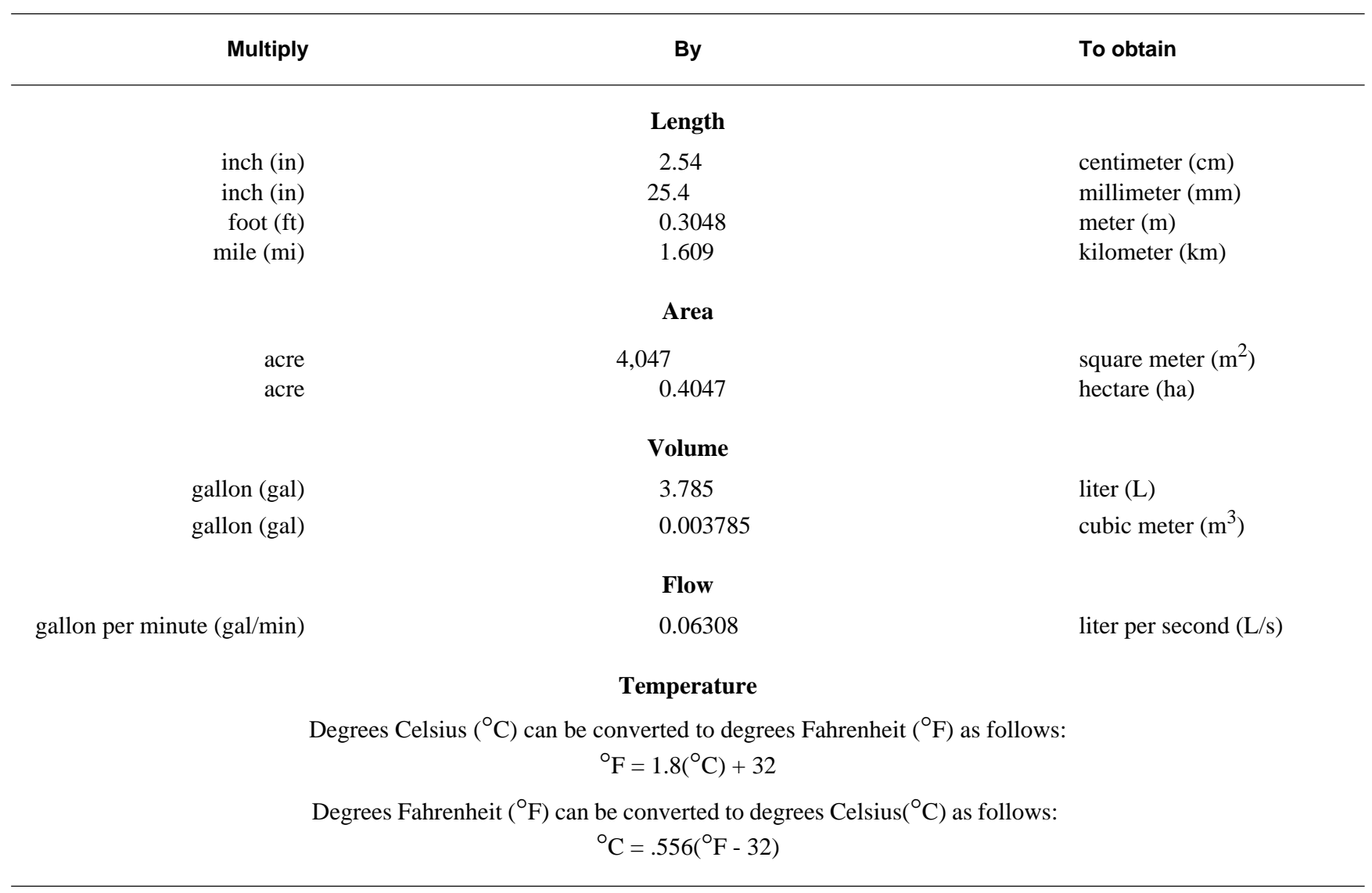

Sea level: In this report "sea level" refers to the National Geodetic Vertical Datum of 1929—a geodetic datum derived from a general adjustment of the first-order level nets of the United States and Canada, formerly called Sea Level Datum of 1929. 



\title{
Hydrologic Data and Description of a Hydrologic Monitoring Plan for the Borax Lake Area, Oregon
}

\author{
By Tiffany Rae Schneider and William D. McFarland
}

\section{Abstract}

Borax Lake is located in southeastern Oregon, within the Alvord Valley Known Geothermal Resource Area. Borax Lake is a large hot spring; there are more than 50 smaller hot springs within about one-half mile to the north of the lake. Several geothermal exploration wells have been drilled near Borax Lake, and there is concern that development of the geothermal resources could affect the lake and nearby hot springs. A factor to consider in developing the resource is that the Borax Lake chub is an endangered species of fish that is found exclusively in Borax Lake.

This study was designed to collect basic hydrologic data to develop a long-term monitoring plan. Baseline data, collected before geothermal production wells are used extensively, will provide an understanding of natural trends and will help identify change caused by development.

Basic data collected during reconnaissance field visits to the area included spring temperatures, specific conductances, and discharge; field measurements in wells included waterlevel measurements and temperature, specific conductance, and discharge measurements in flowing wells. The study of the Borax Lake area included depth and temperature measurements in the vent area of the lake, point velocity measurements, underwater video photography, and an evaluation of methods to measure discharge from the lake. Water-quality samples were collected at Borax Lake, one hot spring, and one flowing well.

Information from field visits was used to develop a monitoring plan. The plan would include monitoring Borax Lake by measuring discharge, stage, evaporation, temperature, and specific conductance; water-quality sampling and analysis; and monitoring shallow groundwater levels near Borax Lake using shallow piezometers. Minimally, one hot spring in North Borax Lake Spring Group 1 would be monitored for temperature and specific conductance and sampled for water-quality analysis. In addition, two flowing wells would be monitored for water levels, temperature, specific conductance, and discharge and sampled for water-quality analysis. The construction characteristics of these wells must be verified before long-term data collection begins. In the future, it may be helpful to monitor shallow and (or) deep observation wells drilled into the thermal aquifer to understand the possible effects of geothermal development on Borax Lake and nearby springs. 


\section{INTRODUCTION}

Although the Pacific Northwest is thought to have abundant hydrothermal resources, they remain essentially undeveloped. To encourage responsible resource development, the Bonneville Power Administration (BPA), with guidance from the Northwest Power Planning Council, is participating in three hydrologic monitoring projects in Oregon. The Known Geothermal Resource Areas of interest are the Vale, Newberry Caldera, and Alvord Valley. A fourth hydrologic monitoring study also was begun in northern California at Medicine Lake Volcano. One of the goals of the pilot projects is to ensure that environmental and land-use issues are adequately evaluated. To accomplish this goal, BPA has begun projects to collect baseline environmental data in advance of geothermal development.

The Alvord Valley Known Geothermal Resource Area has been explored most extensively in the Borax Lake area near Fields, Oregon. In that area, there are specific environmental concerns. On May 28, 1980, the U.S. Fish and Wildlife Service (USFWS) made an emergency determination that the Borax Lake chub, a fish species endemic to Borax Lake, was an endangered species (50 CFR, 17.11; 45 FR 35821). Borax Lake is on private land. The USFWS designated 640 acres, including Borax Lake, nearby hot springs, ponds, and associated shorelines, as critical habitat for the chub. The area included 320 acres of Bureau of Land Management (BLM) land. The USFWS stated that "Additional land is provided as a buffer zone around the aquatic habitat to insure its integrity." The USFWS also warned against geothermal exploration near the lake or modification of spring flow or water temperature.

In January 1991, the U.S. Geological Survey (USGS), in cooperation with BPA, participated in a hydrologic monitoring project by designing and implementing a monitoring plan that will establish a baseline set of current and predevelopment surfaceand ground-water quality and quantity data at and near areas of potential geothermal development.
This report describes reconnaissance, hydrologic monitoring, and the monitoring plan developed by the USGS for the Borax Lake area in the Pueblo Valley, Harney County, Oregon, from March 1991 through September 1992.

\section{Background}

Borax Lake is located near the center of Pueblo Valley, approximately 2 miles south of Alvord Lake, and is approximately 700 feet in diameter (fig. 1). Most of the lake is 2.5 to 3 feet in depth; however, the vent area has been sounded to depths of more than 95 feet. The lake is a large hot spring, and there are more than 50 smaller hot springs to the north within about one-half mile of Borax Lake. The lake and nearby hot springs occur on a north-trending ridge in the valley floor that rises 20 to 25 feet above the surrounding ground. This ridge probably was formed by fault movement and the deposition of siliceous sinter from Borax Lake and the associated hot springs. Inflow temperatures to the lake range from $65^{\circ} \mathrm{C}$ (degrees Celsius) to a possible maximum of $120^{\circ} \mathrm{C}$. Hot springs to the north of the lake have temperatures of up to $93^{\circ} \mathrm{C}$.

The Borax Lake monitoring project was designed to include two phases. Phase I was at a reconnaissance level and Phase II was implementation of a full-scale monitoring plan. Phase I of the project included three field trips to the Borax Lake area. The first trip, in March 1991, included field location of wells and springs near Borax Lake, collection of isotope samples for future analysis, and reconnaissance of streamflow around the lake. After the initial field location of wells and springs, water levels in wells and spring temperatures were measured during each field visit. The second trip, in April 1991, focused on methods of measuring inflow and discharge from the lake. This included depth and temperature measurements in the vent area of the lake, point velocity measurements, and an evaluation of methods used to measure discharge from the lake. The third trip, in July 1991, included further depth and temperature mapping in the vent area and underwater video photography to view the vent. 


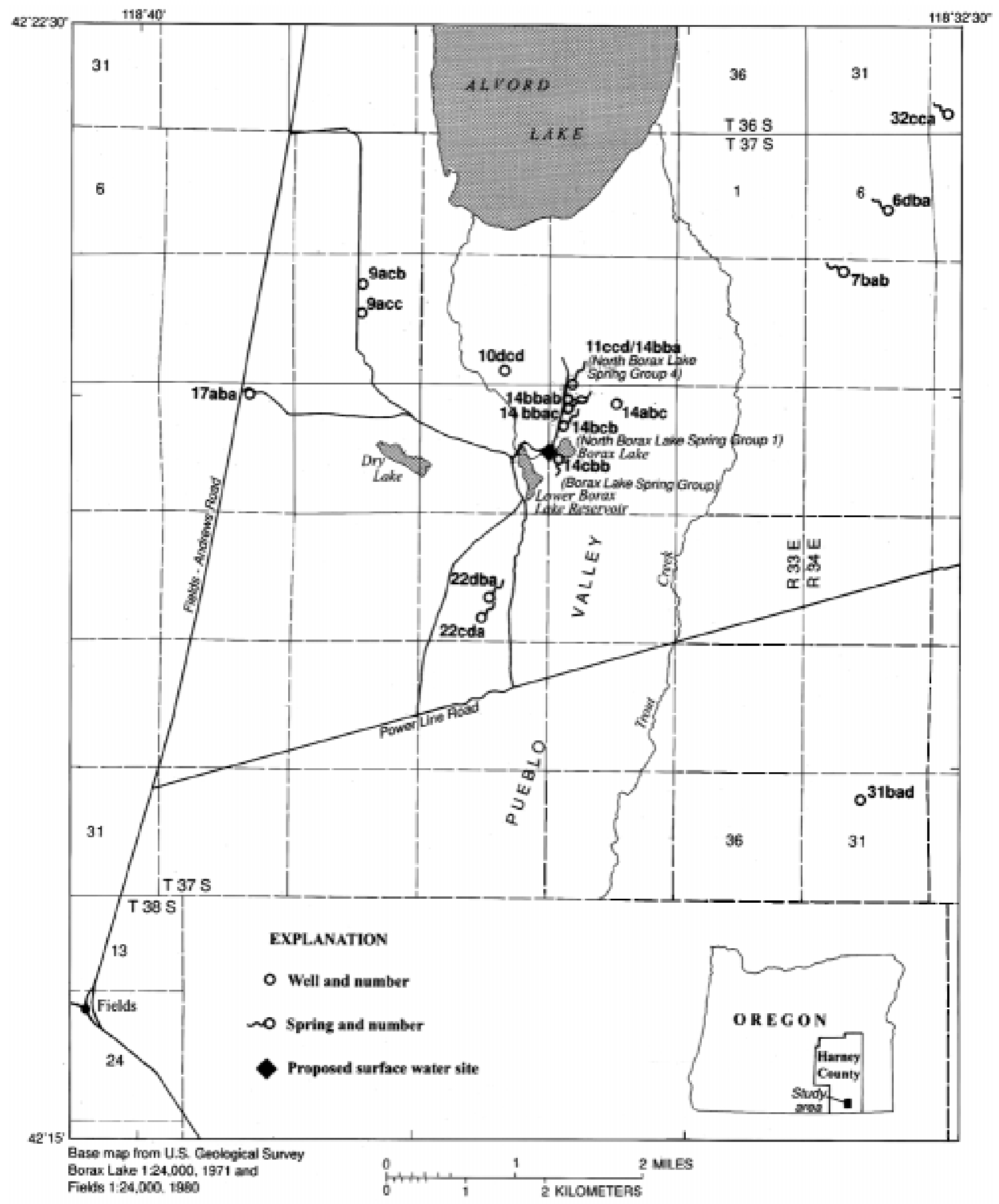

Figure 1. Location of Borax Lake study area, Oregon. 
The feasibility of continuous velocity measurements and the use of continuous monitoring sites in the lake vent at approximately a 90-foot depth was assessed. In addition, consideration was given to monitoring at the nearest hot spring located to the north, and a waterquality sample of inflowing vent water was collected for analysis (sample collected by Robert Mariner, USGS, Menlo Park, California). Information from these three field trips allowed development of a comprehensive monitoring plan. In the event of development, this plan was to be implemented in Phase II of the study.

Borax Lake is contained by a narrow rim of siliceous sinter that is 3 to 5 feet in width and is an average of less than 1 foot high above the lake surface. From the crest of this rim, the land surface slopes away from the lake in all directions. As a result, no surfacewater runoff flows into the lake. However, this rim has been naturally breached in several places by wave action and has been breached by man to irrigate land for cattle grazing. Approximately 8 to 10 channels allow water to discharge from the lake. Some of these channels flow without control and others have been "sandbagged" to regulate the flow and to maintain the level of the lake. Most of these channels flow out of the northeastern shore of the lake; however, two major channels are present on the western edge of the lakeone of these is the channel that at one time supplied water to Lower Borax Lake Reservoir to the west. During much of the study period, Lower Borax Lake Reservoir was dry. However, the water level at Borax Lake is kept at a relatively high stage; therefore, water also seeps through grassy areas on the western and southern rim of the lake. Although an estimate of runoff from Borax Lake was made during the March 1991 field trip, this estimate was of unknown accuracy because of the many avenues of discharge.

During field reconnaissance, it was evident that ground-water discharge also occurs from the lake. Two to three hundred feet southwest of the lake, in the area of the Borax Lake Spring Group (fig. 2), cold water springs with temperatures and specific conductances similar to those of the lake were discharging at rates of 1 to 2 gallons per minute. These springs may be a result of raising the lake level and diversion of some of the lake water to a large pond southwest of the lake.
There are also several areas around the lake where diffuse ground-water seepage occurs.

Variations in the temperature of the geothermal water entering the lake are evident from observed fish kills that have occurred since about 1980. The largest fish kill was noted in July 1987, when 1,500 to 2,000 fish were apparently killed from increased inflow temperatures (Denny Seymour, BLM, written commun., 1991). These events indicate that there have been significant increases in temperature under natural conditions.

The longest-term monitoring at Borax Lake has been conducted by BLM employees (Denny Seymour of Portland, Oregon and Terry Geisler of Burns, Oregon). Their work has included operation of a weather station on the south side of the lake, as well as continuous measurements of lake water temperature. Periodic manual measurements of lake temperature around the lake shore also have been collected on a long-term basis.

\section{Purpose and Scope}

The purpose of this report is to present the data collected in Phase I of the project and describe the monitoring plan for Phase II of the project. A limited amount of data was collected for Phase II of the project, because BPA delegated most of the work on Borax Lake to BLM. The data that were collected by the USGS are included in this report. This initial short data record, collected during this study on the hydrology, water chemistry, and biology of the area, is not sufficient to define baseline conditions for the area and may not be adequate to assess change in the hydrologic and biologic systems in the future when geothermal development occurs. Additional data are needed to establish natural ranges in hot spring temperatures, discharges, and water-quality parameters. Similar data are needed for cold springs and wells in the area.

Phase I of the project (March 1991September 1991) was of limited scope and involved (1) a literature and file search for existing wells, springs, hydrologic data, and technical reports; and 


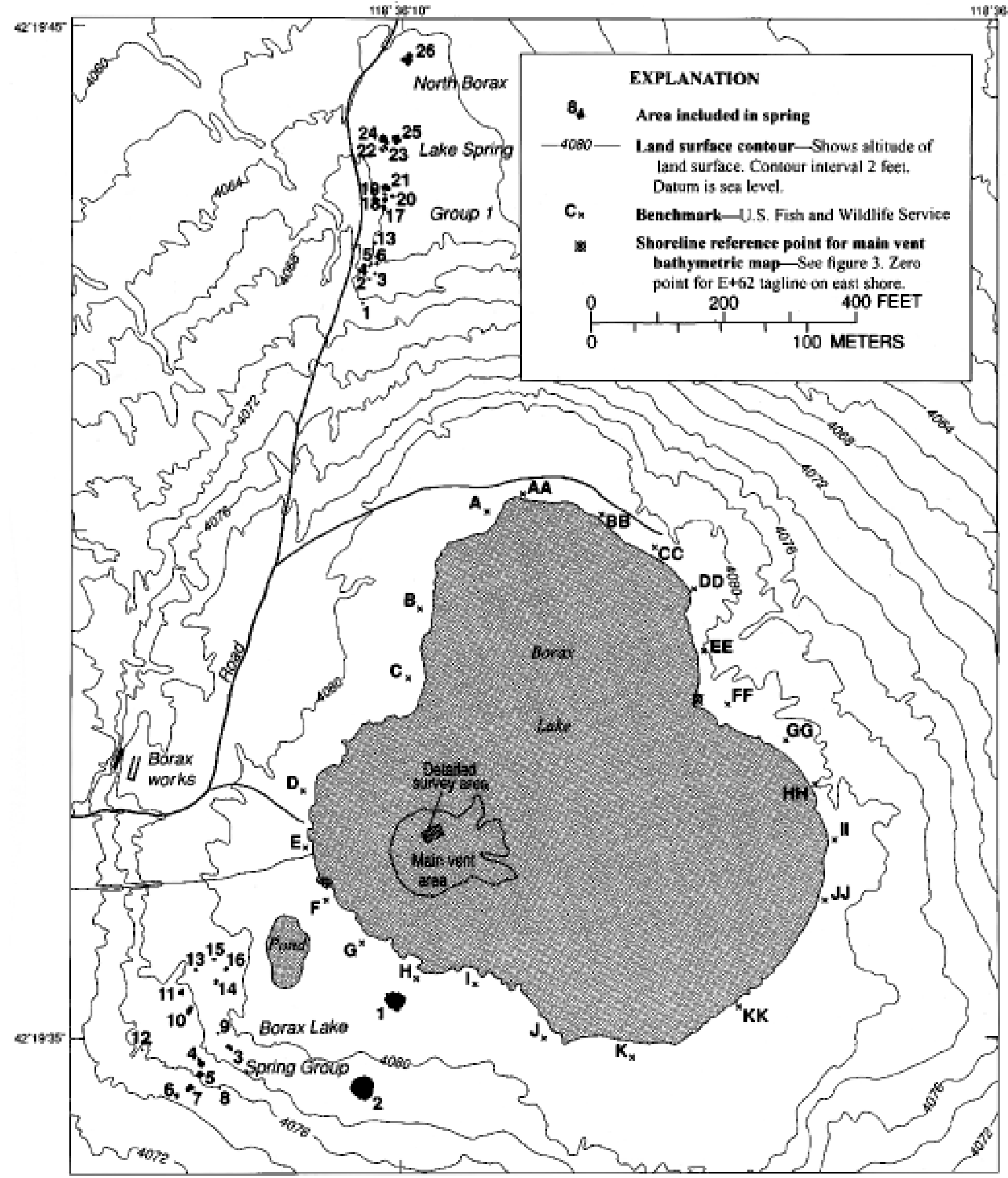

Base mas trom Boenewile Pawiz Admêristration इurver. 1 402. 1991

Figure 2. Location in Oregon of Borax Lake Spring Group, North Borax Lake Spring Group 1, and benchmarks and main vent at Borax Lake. 
(2) reconnaissance field work to locate hydrologic features of interest, make initial measurements, and make other hydrologic observations. Findings from Phase I of the project were used to develop a detailed work plan for Phase II of the study to monitor potential effects of geothermal development. At the end of Phase I, Phase II was not fully implemented because it appeared unlikely that geothermal development would occur. However, a limited network of wells and springs was monitored through September 1992.

The objective of Phase II of the Borax Lake hydrologic monitoring program was to design and implement plans to collect baseline environmental data prior to geothermal development in the area. It was proposed that during fiscal year 1992, Phase II monitoring would begin in the immediate vicinity (within approximately a 1-mile radius) of Borax Lake. Sites of interest included Borax Lake, the shallow ground-water system near Borax Lake (Borax Lake Spring Group), hot springs north of Borax Lake (North Borax Lake Spring Group 1 and Group 4), and wells 37S/33E-14abc and $37 \mathrm{~S} / 33 \mathrm{E}-10 \mathrm{dcd}$. Water levels in other field-located wells were also measured.

\section{DATA-COLLECTION METHODS}

Data were collected for the Borax Lake study using USGS standard methods. Where appropriate, references for these standard methods are included in the following discussion.

\section{Water Levels}

Water levels in wells were collected using a steel engineer's tape calibrated to hundredths of a foot. Two measurements were made within a few minutes of one another at each measurement site, and the measurements were accepted only if they agreed within one-hundredth of a foot. Measuring point and land-surface elevations were established using $1: 24,000$-scale topographic maps published by the USGS.
Water levels in all wells in the study area were made during static conditions during each field visit. None of the wells were used during the period of study.

Flowing wells in the study area have been flowing for many years and no attempt was made to "shut in" these wells for water-level measurement. Accurate discharge measurements were made, however, on flowing wells. Standard USGS waterlevel measurement methods can be found in Garber and Koopman (1968).

\section{Discharge}

Discharge from flowing wells was measured using volumetric methods. Generally, a small wooden flume that channeled the water into one discharge point was placed on top of the well. Discharge was then measured using a bucket and a stop watch. Discharge measurements from springs generally were not made because of the difficulty of channeling flow from the springs into one distinct discharge point that could be measured. The discharge from many of the springs seeps into the ground near their orifices.

\section{Field Water-Quality Data}

Temperature data were collected using a digital thermometer or a combination temperature and specific conductance probe. These instruments were calibrated at the beginning of each day. The thermometer was checked using a mercury thermometer, and the specific conductance meter was checked with conductivity standards that bracketed the range of specific conductances expected in the field.

Samples were taken for analysis of major ions and stable isotopes. These samples were taken from (1) the Borax Lake orifice at a depth of approximately 90 feet, (2) the flowing well 37S/33E-14abc, and (3) a hot spring in North Borax Spring Group 4. Additional isotope samples were collected and archived for later analysis. 


\section{Lake Measurements}

Physical parameters of Borax Lake, including water velocities and lake depth (bathymetry), were measured on Borax Lake itself. The location of each sampling point was established using taglines.

During the April 1991 visit, water velocities in the lake were measured to determine the feasibility of installing an acoustic velocity meter in the vent of the lake to measure inflow of geothermal water. These measurements required using two measuring devicesa Marsh-McBirney electromagnetic velocity meter and a portable acoustic velocity meter. The MarshMcBirney meter was used to measure vertical velocities, and the acoustic velocity meter was used to measure velocities in the $\mathrm{X}$ and $\mathrm{Y}$ directions. These measurements were done for reconnaissance purposes only.

The amount, characteristics, and variability of geothermal water that flows into Borax Lake are poorly understood. Depth and temperature soundings indicate that a single main vent currently supplies water to the lake. Water enters the vent bottom at a depth of approximately 90 feet, but water may also enter the lake from the sides of the orifice. Flow into the vent is diffuse and turbulent and causes convective flow in the lake.

\section{Positioning}

The boat position and measuring locations were established using a tagline that spanned the lake. Twenty-two USFWS benchmarks, located around the perimeter of the lake, were used to determine the location of the tagline anchor points along the rim of the lake. These benchmarks are shown in figure 2 . The tagline used was made of galvanized steel and was marked at 5 -foot intervals with brass beads. The tagline reel was placed on the west shore of the lake and stretched across the lake to the east side. The two end points were located an equal distance southeast of the $\mathrm{E}$ and the EE benchmarks (fig. 2).

\section{Bathymetry}

Detailed bathymetry was done in the central orifice of Borax Lake to help define the vent area (fig. 3). This bathymetry was done by using two taglines aligned parallel to each other, approximately 10 feet apart (fig. 3). By using the double-tagline method, error resulting from strong winds was minimized.

If a single tagline is used there can be up to 2 or 3 feet of error because of winds. The taglines shown in figure 3 were placed by using additional spacing from the original benchmarks in order to map the main vent area more accurately. For example, the destination "E+60" means that the tagline was placed 60 feet southeast of the line between the $\mathrm{E}$ and the $\mathrm{EE}$ benchmarks.

Gas bubbles that enter the lake from the bottom of the orifice of the vent area make using standard depth sounding (sonar) equipment difficult; therefore, all bathymetric measurements were made with a sounding weight and a stream-gaging reel.

\section{Underwater Video Photography}

The vent area of the lake was filmed using an underwater video camera and a light source. The camera and light source were mounted in a galvanized pipe frame about 5 feet long, 2 feet wide, and 2 feet tall. The camera was lowered from the boat (positioned with taglines) to the 90 -foot depth of the central vent. During filming, images of the lake bottom that were observed from the boat were also recorded on video tape.

Underwater video photography showed flow from many small vents within the main orifice and, in some places, an extremely irregular bottom. Also, gas bubbles discharged with the geothermal water from the orifices and floated to the lake surface.

\section{HYDROLOGIC DATA}

\section{Lake}

Temperatures measured in Borax Lake ranged from $18^{\circ} \mathrm{C}$ at the lake's edge to more than $93^{\circ} \mathrm{C}$ where geothermal waters enter the bottom of the vent area. Temperatures measured during this study may not be as high as those reported by others (Denny Seymour, BLM, written commun., 1991), because a 50-pound weight which would not fit into smaller orifices at the bottom of the lake was used. 


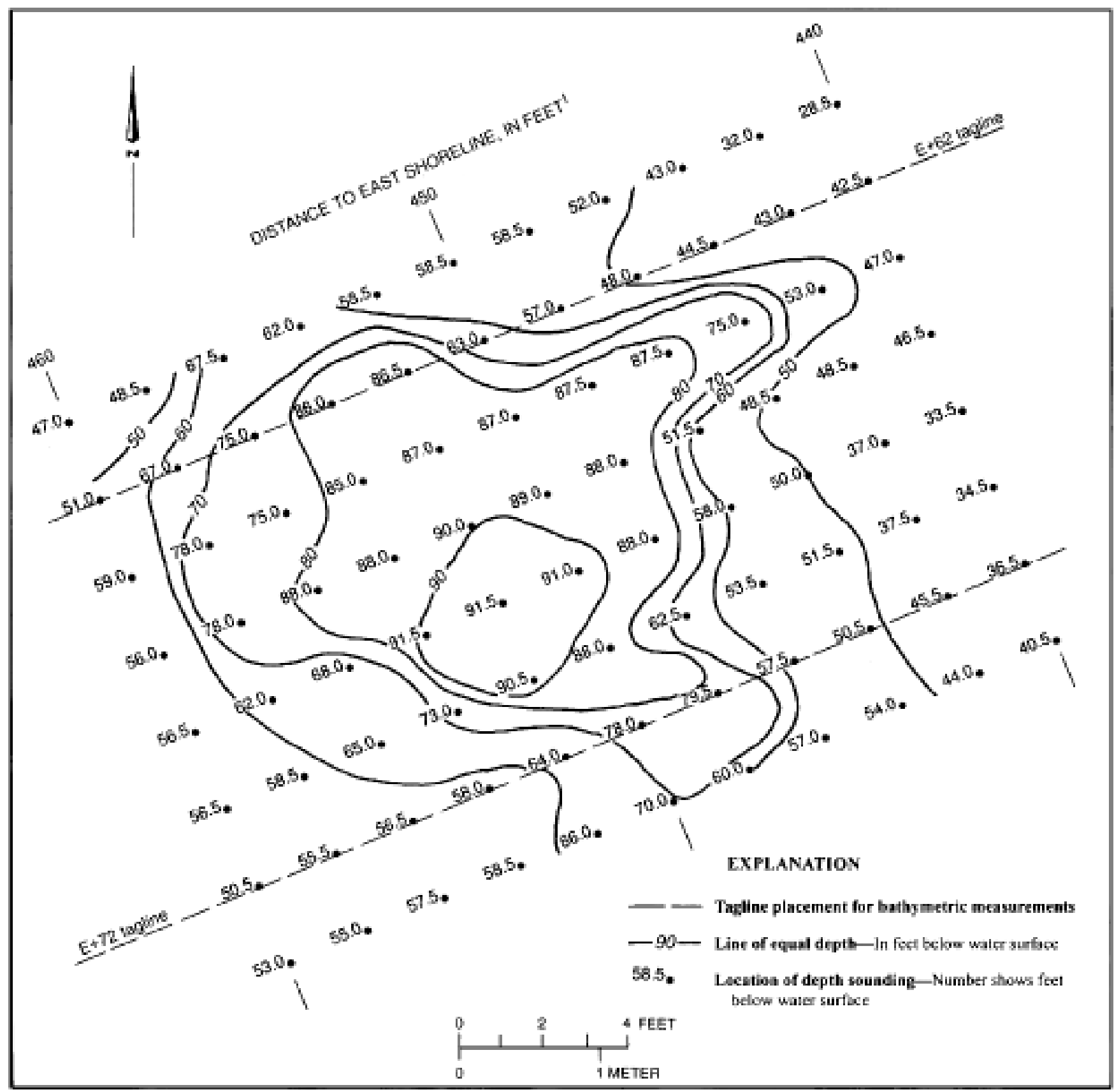

1 Reference point is 10 point on east shoreine for the E+62 tagine.

Figure 3. Bathymetric map of main vent, Borax Lake, Oregon. 
This 50-pound weight was used to assure that the temperature and acoustic velocity probes went into the orifice vertically.

Velocity data were collected to determine the feasibility of using an acoustic velocity meter in the vent area to monitor inflow into the lake. The velocity data were collected at individual points across the lake and at various depths. The movement of water in the lake tends to be convective. In some parts of the vent, turbulent flow is evident. Measured velocities ranged from 0 to more than 15 centimeters per second. In the bottom of the vent, the direction of flow rotated in all directions. Observations made later using the underwater video camera showed that gas bubbles enter the lake in the bottom of the vent area. Individual measurements of flow, taken during a period of several hours, proved difficult to interpret.

The velocity measurements and underwater video photography also indicated that water flows into the lake from many small holes, rather than from one large hole at the bottom of the vent. These small holes occur near the bottom of the main vent, as well as along the walls of the main vent.

\section{Springs}

The hot springs near Borax Lake exist in many forms (figs. 2 and 4), and the water in these springs has temperatures that vary from $5^{\circ} \mathrm{C}$ to $100^{\circ} \mathrm{C}$. The springs can be placed in five groups for discussion purposes. These groups include Borax Lake Spring Group southwest of Borax Lake and four spring groups north of Borax Lake called North Borax Lake Spring Groups 1, 2, 3, and 4. The Borax Lake Spring Group is a group of warm water springs which may be caused primarily by ground-water seepage from Borax Lake. However, the North Borax Spring Groups include some springs that have temperatures approaching $100^{\circ} \mathrm{C}$; water temperatures in the hot springs at the spring orifice can vary during a 24 -hour period by as much as $10^{\circ} \mathrm{C}$.
In some cases, temperatures can vary inversely in hot springs adjacent to one another. For example, one of the two springs may have a higher temperature one day, but the next day the other spring may have the higher temperature. Because the temperature of some springs changes with atmospheric temperature, the temperature of those springs are changing constantly.

Most springs in the Borax Lake Spring Group are essentially inactive; however, a few smaller springs $(8,9$, and 12$)$ in the spring group have been observed to discharge approximately 1 to 2 gallons of water per minute from 3- to 6-inch orifices. The specific conductance of the water in these three springs (2,200-2,470 $\mu \mathrm{S} / \mathrm{cm}$ [microsiemens per centimeter]) and the specific conductance of water in Borax Lake $(2,140 \mu \mathrm{S} / \mathrm{cm})$ was similar on March 21, 1991, whereas the other springs in the group could have significantly higher specific conductances (table 1). These different specific conductances could indicate different sources of thermal water to the springs.

Data collection on springs north of Borax Lake focused on groups 1 and 4 . These two spring groups have more than 20 active springs that were observed during this study. Hot springs in groups 2 and 3 are fewer in number and were not measured during this study.

\section{Wells}

Six wells were field located in the Pueblo Valley near Borax Lake. Two of the wells nearest the lake are warm flowing wells. Well 37S/33E$14 \mathrm{abc}$ (fig. 1) discharges 17 to 25 gallons per minute. The well-water temperature ranges consistently from 56 to $58^{\circ} \mathrm{C}$, and specific conductance has been measured between about 1,800 and $2,100 \mu \mathrm{S} / \mathrm{cm}$. Well 37S/33E-10dcd (fig. 1) discharges 28 to 55 gallons per minute, has a consistent temperature of $16^{\circ} \mathrm{C}$, and a measured specific conductance of between 250 and $281 \mu \mathrm{S} / \mathrm{cm}$. No attempt was made to measure static water levels in either flowing well. 


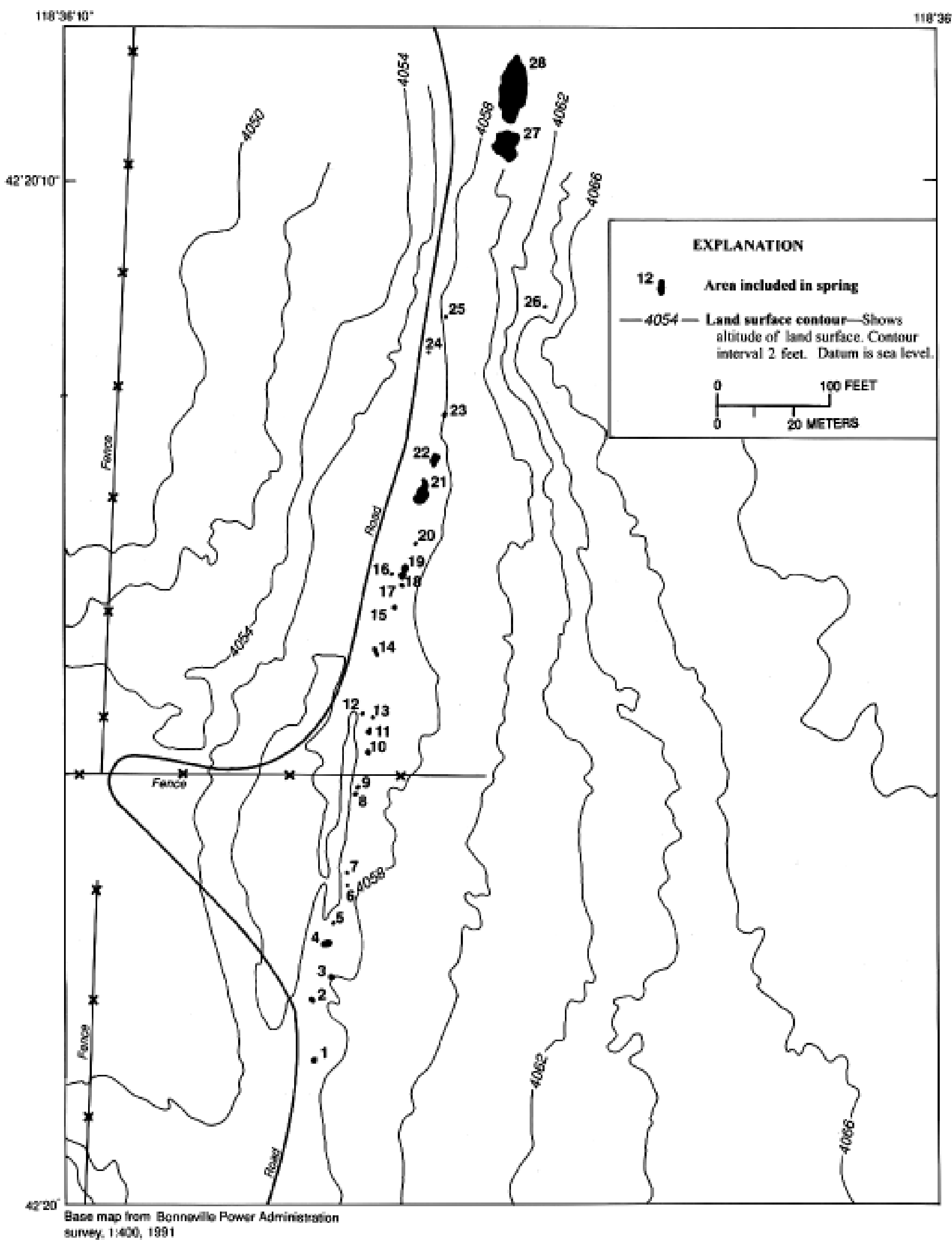

Figure 4. Location of North Borax Lake Spring Group 4, Oregon. 
Table 1. Records of selected springs in the Pueblo Valley, Oregon

Spring location number:

Spring identification Number:

Latitude:

Longitude:

Altitude:

Temperature:

Specific conductance:
Refer to explanation and diagram of Well-Numbering System.

Identification number permanently assigned to spring.

Latitude of spring in ', degrees; ', minutes; ", seconds.

Longitude of spring in ${ }^{\circ}$, degrees; ', minutes; ", seconds.

Altitude of land surface at spring, in feet above mean sea level, estimated from topographic maps.

Field measurement by U.S. Geological Survey or reported value.

In microsiemens per centimeter at 25 degrees Celsius.

\begin{tabular}{|c|c|c|c|c|c|c|c|c|}
\hline $\begin{array}{l}\text { Spring } \\
\text { location } \\
\text { number }\end{array}$ & $\begin{array}{l}\text { Spring } \\
\text { name }\end{array}$ & $\begin{array}{c}\text { Spring } \\
\text { identification } \\
\text { number }\end{array}$ & ' Latitude Longitude & $\begin{array}{c}\text { Altitude } \\
\text { (feet) }\end{array}$ & Date & $\begin{array}{l}\text { Temperature } \\
\text { (in degrees } \\
\text { Celsius) }\end{array}$ & $\begin{array}{l}\text { Specific } \\
\text { conductance }\end{array}$ & Remarks \\
\hline 36S/34E-32cca & Buckbrush & $\begin{array}{l}-- \\
-- \\
--\end{array}$ & $42^{\circ} 21^{\prime} 54^{\prime \prime} 124^{\circ} 32^{\prime} 37^{\prime \prime}$ & 4,045 & $\begin{array}{l}4 / 02 / 92 \\
7 / 01 / 92 \\
9 / 10 / 92\end{array}$ & $\begin{array}{l}22.7 \\
22.1 \\
22.2\end{array}$ & $\begin{array}{l}2,870 \\
2,460 \\
2,470\end{array}$ & \\
\hline \multirow{13}{*}{$\begin{array}{l}37 \mathrm{~S} / 33 \mathrm{E}-14 \mathrm{cbb} \\
\text { ramp }\end{array}$} & Borax Lake & -- & $42^{\circ} 19^{\prime} 35^{\prime \prime} 124^{\circ} 36^{\prime} 10^{\prime \prime}$ & 4,075 & $3 / 21 / 91$ & 24.7 & 2,140 & At boat \\
\hline & & $\begin{array}{l}-- \\
-- \\
--\end{array}$ & & & $\begin{array}{l}4 / 01 / 92 \\
6 / 29 / 92 \\
9 / 09 / 92\end{array}$ & $\begin{array}{l}27.8 \\
26.8 \\
32.9\end{array}$ & $\begin{array}{l}2,120 \\
2,090 \\
2,050\end{array}$ & \\
\hline & Borax Lake Pond & $\begin{array}{l}-- \\
-- \\
-- \\
--\end{array}$ & $42^{\circ} 19^{\prime} 36^{\prime \prime} 124^{\circ} 36^{\prime} 12^{\prime \prime}$ & 4,079 & $\begin{array}{l}3 / 21 / 91 \\
4 / 01 / 92 \\
6 / 29 / 92 \\
9 / 09 / 92\end{array}$ & $\begin{array}{l}15.2 \\
24.8 \\
25.6 \\
26.9\end{array}$ & $\begin{array}{l}2,120 \\
2,120 \\
2,110 \\
2,070\end{array}$ & Pond \\
\hline & Borax Lake Spring Group & 1 & $42^{\circ} 19^{\prime} 36^{\prime \prime} 124^{\circ} 36^{\prime} 13^{\prime \prime}$ & 4,078 & $\begin{array}{l}3 / 21 / 91 \\
4 / 01 / 92 \\
6 / 29 / 92 \\
9 / 09 / 92\end{array}$ & $\begin{array}{l}10.0 \\
12.5 \\
21.0 \\
18.9\end{array}$ & $\begin{array}{l}2,140 \\
2,640 \\
2,840 \\
3,200\end{array}$ & \\
\hline & Borax Lake Spring Group & 2 & $42^{\circ} 19^{\prime} 36^{\prime \prime} 124^{\circ} 36^{\prime} 13^{\prime \prime}$ & 4,078 & $\begin{array}{l}3 / 21 / 91 \\
4 / 01 / 92 \\
6 / 29 / 92 \\
9 / 09 / 92\end{array}$ & $\begin{array}{r}6.0 \\
11.2 \\
20.6 \\
20.4\end{array}$ & $\begin{array}{l}3,170 \\
3,060 \\
8,450 \\
7,740\end{array}$ & \\
\hline & Borax Lake Spring Group & 3 & $42^{\circ} 19^{\prime} 36^{\prime \prime} 124^{\circ} 36^{\prime} 13^{\prime \prime}$ & 4,078 & $\begin{array}{l}3 / 21 / 91 \\
4 / 01 / 92 \\
6 / 29 / 92 \\
9 / 09 / 92\end{array}$ & $\begin{array}{r}8.3 \\
12.3 \\
21.2 \\
19.2\end{array}$ & $\begin{array}{l}3,780 \\
2,220 \\
2,320 \\
2,240\end{array}$ & \\
\hline & Borax Lake Spring Group & 4 & $42^{\circ} 19^{\prime} 36^{\prime \prime} 124^{\circ} 36^{\prime} 13^{\prime \prime}$ & 4,078 & $\begin{array}{l}3 / 21 / 91 \\
4 / 01 / 92 \\
6 / 29 / 92 \\
9 / 09 / 92\end{array}$ & $\begin{array}{r}9.1 \\
12.7 \\
21.5 \\
21.1\end{array}$ & $\begin{array}{l}4,980 \\
2,190 \\
2,270 \\
2,320\end{array}$ & \\
\hline & Borax Lake Spring Group & 5 & $42^{\circ} 19^{\prime} 36^{\prime \prime} 124^{\circ} 36^{\prime} 13^{\prime \prime}$ & 4,078 & $\begin{array}{l}3 / 21 / 91 \\
4 / 01 / 92 \\
6 / 29 / 92 \\
9 / 09 / 92\end{array}$ & $\begin{array}{r}8.9 \\
12.2 \\
21.1 \\
20.3\end{array}$ & $\begin{array}{l}5,500 \\
2,200 \\
2,290 \\
2,370\end{array}$ & \\
\hline & Borax Lake Spring Group & 6 & $42^{\circ} 19^{\prime} 36^{\prime \prime} 124^{\circ} 36^{\prime} 13^{\prime \prime}$ & 4,078 & $\begin{array}{l}3 / 21 / 91 \\
4 / 01 / 92 \\
6 / 29 / 92 \\
9 / 09 / 92\end{array}$ & $\begin{array}{r}9.3 \\
9.9 \\
19.1 \\
16.9\end{array}$ & $\begin{array}{l}5,450 \\
2,310 \\
2,480 \\
2,610\end{array}$ & \\
\hline & Borax Lake Spring Group & 7 & $42^{\circ} 19^{\prime} 36^{\prime \prime} 124^{\circ} 36^{\prime} 13^{\prime \prime}$ & 4,078 & $\begin{array}{l}3 / 21 / 91 \\
4 / 01 / 92 \\
6 / 29 / 92 \\
9 / 09 / 92\end{array}$ & $\begin{array}{r}6.0 \\
10.8 \\
19.3 \\
15.2\end{array}$ & $\begin{array}{l}3,480 \\
2,290 \\
2,380 \\
2,500\end{array}$ & \\
\hline & Borax Lake Spring Group & 8 & $42^{\circ} 19^{\prime} 36^{\prime \prime} 124^{\circ} 36^{\prime} 13^{\prime \prime}$ & 4,078 & $\begin{array}{l}3 / 21 / 91 \\
4 / 01 / 92\end{array}$ & $\begin{array}{l}11.9 \\
11.7\end{array}$ & $\begin{array}{l}2,470 \\
2,160\end{array}$ & \\
\hline & Borax Lake Spring Group & 9 & $42^{\circ} 19^{\prime} 36^{\prime \prime} 124^{\circ} 36^{\prime} 13^{\prime \prime}$ & 4,078 & $3 / 21 / 91$ & 14.0 & 2,200 & \\
\hline & Borax Lake Spring Group & 10 & $42^{\circ} 19^{\prime} 36^{\prime \prime} 124^{\circ} 36^{\prime} 13^{\prime \prime}$ & 4,078 & $\begin{array}{l}3 / 21 / 91 \\
4 / 01 / 92 \\
6 / 29 / 92 \\
9 / 09 / 92\end{array}$ & $\begin{array}{r}8.0 \\
18.5 \\
24.4 \\
23.5\end{array}$ & $\begin{array}{l}3,430 \\
2,130 \\
2,140 \\
2,150\end{array}$ & \\
\hline
\end{tabular}


Table 1. Records of selected springs in the Pueblo Valley, Oregon—Continued

\begin{tabular}{|c|c|c|c|c|c|c|c|c|}
\hline $\begin{array}{l}\text { Spring } \\
\text { location } \\
\text { number }\end{array}$ & $\begin{array}{l}\text { Spring } \\
\text { name }\end{array}$ & $\begin{array}{c}\text { Spring } \\
\text { identification } \\
\text { number }\end{array}$ & ' Latitude Longitude & $\begin{array}{c}\text { Altitude } \\
\text { (feet) }\end{array}$ & Date & $\begin{array}{l}\text { Temperature } \\
\text { (in degrees } \\
\text { (Celsius) }\end{array}$ & $\begin{array}{l}\text { Specific } \\
\text { conductance }\end{array}$ & Remarks \\
\hline & Borax Lake Spring Group & 11 & $42^{\circ} 19^{\prime} 36^{\prime \prime} 124^{\circ} 36^{\prime} 13^{\prime \prime}$ & 4,078 & $\begin{array}{l}3 / 21 / 91 \\
4 / 01 / 92 \\
6 / 29 / 92 \\
9 / 09 / 92\end{array}$ & $\begin{array}{l}11.0 \\
20.3 \\
24.3 \\
24.7\end{array}$ & $\begin{array}{l}2,300 \\
2,120 \\
2,140 \\
2,120\end{array}$ & \\
\hline & Borax Lake Spring Group & 12 & $42^{\circ} 19^{\prime} 36^{\prime \prime} 124^{\circ} 36^{\prime} 13^{\prime \prime}$ & 4,078 & $3 / 21 / 91$ & 11.8 & 2,310 & \\
\hline & Borax Lake Spring Group & 13 & $42^{\circ} 19^{\prime} 36^{\prime \prime} 124^{\circ} 36^{\prime} 13^{\prime \prime}$ & 4,078 & $\begin{array}{l}3 / 21 / 91 \\
4 / 01 / 92 \\
6 / 29 / 92 \\
9 / 09 / 92\end{array}$ & $\begin{array}{r}8.1 \\
17.8 \\
24.1 \\
24.5\end{array}$ & $\begin{array}{l}3,280 \\
2,170 \\
2,130 \\
2,100\end{array}$ & \\
\hline & Borax Lake Spring Group & 14 & $42^{\circ} 19^{\prime} 36^{\prime \prime} 124^{\circ} 36^{\prime} 13^{\prime \prime}$ & 4,078 & $\begin{array}{l}3 / 21 / 91 \\
4 / 01 / 92 \\
6 / 29 / 92 \\
9 / 09 / 92\end{array}$ & $\begin{array}{r}9.9 \\
21.3 \\
24.3 \\
26.6\end{array}$ & $\begin{array}{l}2,640 \\
2,150 \\
2,130 \\
2,110\end{array}$ & \\
\hline & Borax Lake Spring Group & 15 & $42^{\circ} 19^{\prime} 36^{\prime \prime} 124^{\circ} 36^{\prime} 13^{\prime \prime}$ & 4,078 & $\begin{array}{l}3 / 21 / 91 \\
4 / 01 / 92 \\
6 / 29 / 92 \\
9 / 09 / 92\end{array}$ & $\begin{array}{r}5.7 \\
23.1 \\
23.9 \\
26.2\end{array}$ & $\begin{array}{l}3,060 \\
2,180 \\
2,120 \\
2,080\end{array}$ & \\
\hline & Borax Lake Spring Group & 16 & $42^{\circ} 19^{\prime} 36^{\prime \prime} 124^{\circ} 36^{\prime} 13^{\prime \prime}$ & 4,078 & $\begin{array}{l}3 / 21 / 91 \\
4 / 01 / 92 \\
6 / 29 / 92\end{array}$ & $\begin{array}{r}9.3 \\
24.8 \\
24.9\end{array}$ & $\begin{array}{l}2,300 \\
2,140 \\
2,120\end{array}$ & \\
\hline $37 \mathrm{~S} / 33 \mathrm{E}-11 \mathrm{ccd}$ & $\begin{array}{l}\text { North Borax Lake Group } 4 \\
\text { and 14bba }\end{array}$ & 1 & $42^{\circ} 20^{\prime} 03^{\prime \prime} 124^{\circ} 36^{\prime} 05^{\prime \prime}$ & 4,053 & $\begin{array}{l}3 / 20 / 91 \\
7 / 13 / 91 \\
4 / 01 / 92 \\
6 / 30 / 92 \\
9 / 09 / 92\end{array}$ & $\begin{array}{l}58.2 \\
61.6 \\
58.3 \\
57.8 \\
59.4\end{array}$ & $\begin{array}{l}2,150 \\
-- \\
2,125 \\
1,810 \\
1,847\end{array}$ & \\
\hline $37 \mathrm{~S} / 33 \mathrm{E}-11 \mathrm{ccd}$ & $\begin{array}{l}\text { North Borax Lake Group } 4 \\
\text { and } 14 \mathrm{bba}\end{array}$ & 2 & $42^{\circ} 20^{\prime} 03^{\prime \prime} 124^{\circ} 36^{\prime} 05^{\prime \prime}$ & 4,053 & $\begin{array}{l}3 / 20 / 91 \\
7 / 13 / 91 \\
4 / 01 / 92 \\
6 / 30 / 92 \\
9 / 09 / 92\end{array}$ & $\begin{array}{l}90.8 \\
91.5 \\
94.3 \\
91.4 \\
94.3\end{array}$ & $\begin{array}{l}2,310 \\
-- \\
2,137 \\
2,130 \\
2,180\end{array}$ & \\
\hline $37 \mathrm{~S} / 33 \mathrm{E}-11 \mathrm{ccd}$ & $\begin{array}{l}\text { North Borax Lake Group } 4 \\
\text { and 14bba }\end{array}$ & 4 & $42^{\circ} 20^{\prime} 03^{\prime \prime} 124^{\circ} 36^{\prime} 05^{\prime \prime}$ & 4,053 & $\begin{array}{l}3 / 20 / 91 \\
7 / 13 / 91 \\
4 / 01 / 92 \\
6 / 30 / 92 \\
9 / 09 / 92\end{array}$ & $\begin{array}{l}84.4 \\
85.6 \\
85.2 \\
83.0 \\
86.2\end{array}$ & $\begin{array}{l}2,340 \\
-- \\
2,296 \\
2,130 \\
2,170\end{array}$ & Arch Spring \\
\hline $37 \mathrm{~S} / 33 \mathrm{E}-11 \mathrm{ccd}$ & $\begin{array}{l}\text { North Borax Lake Group } 4 \\
\text { and 14bba }\end{array}$ & 7 & $42^{\circ} 20^{\prime} 03^{\prime \prime} 124^{\circ} 36^{\prime} 05^{\prime \prime}$ & 4,053 & $\begin{array}{l}3 / 20 / 91 \\
7 / 13 / 91 \\
4 / 01 / 92 \\
6 / 30 / 92 \\
9 / 09 / 92\end{array}$ & $\begin{array}{l}85.5 \\
87.6 \\
89.4 \\
83.1 \\
88.1\end{array}$ & $\begin{array}{l}2,210 \\
-- \\
2,094 \\
2,010 \\
2,050\end{array}$ & \\
\hline $37 \mathrm{~S} / 33 \mathrm{E}-11 \mathrm{ccd}$ & $\begin{array}{l}\text { North Borax Lake Group } 4 \\
\text { and 14bba }\end{array}$ & 13 & $42^{\circ} 20^{\prime} 03 " 124^{\circ} 36^{\prime} 05^{\prime \prime}$ & 4,053 & $\begin{array}{l}3 / 20 / 91 \\
7 / 13 / 91 \\
4 / 01 / 92 \\
6 / 30 / 92 \\
9 / 09 / 92\end{array}$ & $\begin{array}{l}93.7 \\
94.9 \\
95.2 \\
93.4 \\
95.1\end{array}$ & $\begin{array}{l}2,380 \\
-- \\
2,221 \\
2,220 \\
2,250\end{array}$ & \\
\hline $37 \mathrm{~S} / 33 \mathrm{E}-11 \mathrm{ccd}$ & $\begin{array}{l}\text { North Borax Lake Group } 4 \\
\text { and 14bba }\end{array}$ & 21 & $42^{\circ} 20^{\prime} 03^{\prime \prime} 124^{\circ} 36^{\prime} 05^{\prime \prime}$ & 4,053 & $\begin{array}{l}3 / 20 / 91 \\
4 / 01 / 92 \\
9 / 09 / 92\end{array}$ & $\begin{array}{l}31.5 \\
32.0 \\
32.5\end{array}$ & $\begin{array}{l}2,230 \\
2,105 \\
1,957\end{array}$ & \\
\hline $37 \mathrm{~S} / 33 \mathrm{E}-11 \mathrm{ccd}$ & $\begin{array}{l}\text { North Borax Lake Group } 4 \\
\text { and 14bba }\end{array}$ & 25 & $42^{\circ} 20^{\prime} 03^{\prime \prime} 124^{\circ} 36^{\prime} 05^{\prime \prime}$ & 4,053 & $\begin{array}{l}3 / 20 / 91 \\
4 / 01 / 92 \\
6 / 30 / 92 \\
9 / 09 / 92\end{array}$ & $\begin{array}{l}77.1 \\
77.3 \\
71.2 \\
76.1\end{array}$ & $\begin{array}{l}2,210 \\
2,165 \\
1,940 \\
1,974\end{array}$ & \\
\hline
\end{tabular}


Table 1. Records of selected springs in the Pueblo Valley, Oregon-Continued

\begin{tabular}{|c|c|c|c|c|c|c|c|c|}
\hline $\begin{array}{l}\text { Spring } \\
\text { location } \\
\text { number }\end{array}$ & $\begin{array}{l}\text { Spring } \\
\text { name }\end{array}$ & $\begin{array}{c}\text { Spring } \\
\text { identification } \\
\text { number }\end{array}$ & Latitude Longitude & $\begin{array}{c}\text { Altitude } \\
\text { (feet) }\end{array}$ & Date & $\begin{array}{c}\text { Temperature } \\
\text { (in degrees } \\
\text { (Celsius) }\end{array}$ & $\begin{array}{c}\text { Specific } \\
\text { conductance }\end{array}$ & Remarks \\
\hline $37 \mathrm{~S} / 33 \mathrm{E}-11 \mathrm{ccd}$ & $\begin{array}{l}\text { North Borax Lake Group } 4 \\
\text { and } 14 \mathrm{bba}\end{array}$ & 26 & $42^{\circ} 20^{\prime} 03^{\prime \prime} 124^{\circ} 36^{\prime} 05^{\prime \prime}$ & 4,053 & $\begin{array}{l}4 / 01 / 92 \\
6 / 30 / 92 \\
9 / 09 / 92\end{array}$ & $\begin{array}{l}74.0 \\
69.0 \\
76.4\end{array}$ & $\begin{array}{l}2,096 \\
1,980 \\
1,967\end{array}$ & \\
\hline $37 \mathrm{~S} / 33 \mathrm{E}-11 \mathrm{ccd}$ & $\begin{array}{l}\text { North Borax Lake Group } 4 \\
\text { and 14bba }\end{array}$ & 27 & $42^{\circ} 20^{\prime} 033^{\prime \prime} 124^{\circ} 36^{\prime} 05^{\prime \prime}$ & 4,053 & $\begin{array}{l}3 / 20 / 91 \\
7 / 13 / 91 \\
4 / 01 / 92 \\
6 / 30 / 92 \\
9 / 09 / 92\end{array}$ & $\begin{array}{l}42.8 \\
55.8 \\
44.5 \\
41.5 \\
39.0\end{array}$ & $\begin{array}{l}2,180 \\
-- \\
2,201 \\
1,870 \\
1,887\end{array}$ & \\
\hline $37 \mathrm{~S} / 33 \mathrm{E}-11 \mathrm{ccd}$ & $\begin{array}{l}\text { North Borax Lake Group } 4 \\
\text { and 14bba }\end{array}$ & 28 & $42^{\circ} 20^{\prime} 03^{\prime \prime} 124^{\circ} 36^{\prime} 05^{\prime \prime}$ & 4,053 & $\begin{array}{l}3 / 20 / 91 \\
7 / 13 / 91 \\
4 / 01 / 92 \\
6 / 30 / 92 \\
9 / 09 / 92\end{array}$ & $\begin{array}{l}42.8 \\
37.3 \\
44.7 \\
40.8 \\
43.6\end{array}$ & $\begin{array}{l}2,180 \\
-- \\
2,231 \\
1,900 \\
1,939\end{array}$ & \\
\hline $37 \mathrm{~S} / 33 \mathrm{E}-14 \mathrm{bcb}$ & North Borax Lake Group 1 & 1 & $42^{\circ} 19^{\prime} 49^{\prime \prime} 124^{\circ} 36^{\prime} 09^{\prime \prime}$ & 4,065 & $\begin{array}{l}3 / 20 / 91 \\
7 / 09 / 92 \\
7 / 13 / 92 \\
4 / 01 / 92 \\
6 / 30 / 92 \\
9 / 09 / 92\end{array}$ & $\begin{array}{l}29.6 \\
80.4 \\
80.1 \\
81.7 \\
79.2 \\
74.3\end{array}$ & $\begin{array}{l}2,560 \\
-- \\
-- \\
2,430 \\
2,160 \\
2,110\end{array}$ & \\
\hline $37 \mathrm{~S} / 33 \mathrm{E}-14 \mathrm{bcb}$ & North Borax Lake Group 1 & 2 & $42^{\circ} 19^{\prime} 49^{\prime \prime} 124^{\circ} 36^{\prime} 09^{\prime \prime}$ & 4,065 & $\begin{array}{l}3 / 20 / 91 \\
4 / 01 / 92 \\
6 / 30 / 92 \\
9 / 09 / 92\end{array}$ & $\begin{array}{l}69.5 \\
57.3 \\
59.6 \\
63.5\end{array}$ & $\begin{array}{l}2,330 \\
1,990 \\
1,970 \\
1,990\end{array}$ & \\
\hline $37 \mathrm{~S} / 33 \mathrm{E}-14 \mathrm{bcb}$ & North Borax Lake Group 1 & 3 & $42^{\circ} 19^{\prime} 49^{\prime \prime} 124^{\circ} 36^{\prime} 09^{\prime \prime}$ & 4,065 & $\begin{array}{l}3 / 20 / 91 \\
4 / 01 / 92 \\
6 / 30 / 92\end{array}$ & $\begin{array}{l}64.4 \\
63.1 \\
54.3\end{array}$ & $\begin{array}{l}2,240 \\
2,090 \\
1,890\end{array}$ & \\
\hline $37 \mathrm{~S} / 33 \mathrm{E}-14 \mathrm{bcb}$ & North Borax Lake Group 1 & 4 & $42^{\circ} 19^{\prime} 49^{\prime \prime} 124^{\circ} 36^{\prime} 09^{\prime \prime}$ & 4,065 & $\begin{array}{l}3 / 20 / 91 \\
7 / 09 / 91 \\
7 / 13 / 91 \\
4 / 01 / 92 \\
6 / 30 / 92 \\
9 / 09 / 92\end{array}$ & $\begin{array}{l}46.2 \\
64.6 \\
68.5 \\
70.2 \\
67.7 \\
70.5\end{array}$ & $\begin{array}{l}3,310 \\
-- \\
-- \\
2,320 \\
2,140 \\
2,080\end{array}$ & \\
\hline $37 \mathrm{~S} / 33 \mathrm{E}-14 \mathrm{bcb}$ & North Borax Lake Group 1 & 5 & $42^{\circ} 19^{\prime} 49^{\prime \prime} 124^{\circ} 36^{\prime} 09^{\prime \prime}$ & 4,065 & $\begin{array}{l}3 / 20 / 91 \\
7 / 13 / 91 \\
4 / 01 / 92 \\
9 / 09 / 92\end{array}$ & $\begin{array}{l}90.8 \\
87.0 \\
88.7 \\
87.5\end{array}$ & $\begin{array}{l}2,410 \\
-- \\
2,070 \\
2,190\end{array}$ & \\
\hline $37 \mathrm{~S} / 33 \mathrm{E}-14 \mathrm{bcb}$ & North Borax Lake Group 1 & 6 & $42^{\circ} 19^{\prime} 49^{\prime \prime} 124^{\circ} 36^{\prime} 09^{\prime \prime}$ & 4,065 & $\begin{array}{l}3 / 20 / 91 \\
7 / 13 / 91 \\
4 / 01 / 92 \\
6 / 30 / 92 \\
9 / 09 / 92\end{array}$ & $\begin{array}{l}50.3 \\
58.1 \\
65.5 \\
71.1 \\
50.1\end{array}$ & $\begin{array}{l}2,720 \\
-- \\
2,130 \\
2,240 \\
1,970\end{array}$ & \\
\hline 37S/33E-14bcb & North Borax Lake Group 1 & 13 & $42^{\circ} 19^{\prime} 49^{\prime \prime} 124^{\circ} 36^{\prime} 09^{\prime \prime}$ & 4,065 & $3 / 20 / 91$ & 56.0 & 2,390 & \\
\hline $37 \mathrm{~S} / 33 \mathrm{E}-14 \mathrm{bcb}$ & North Borax Lake Group 1 & 15 & $42^{\circ} 19^{\prime} 49^{\prime \prime} 124^{\circ} 36^{\prime} 09^{\prime \prime}$ & 4,065 & $\begin{array}{l}3 / 20 / 91 \\
4 / 01 / 92 \\
6 / 30 / 92 \\
9 / 09 / 92\end{array}$ & $\begin{array}{l}48.6 \\
54.6 \\
50.7 \\
47.1\end{array}$ & $\begin{array}{l}2,420 \\
2,120 \\
2,110 \\
1,990\end{array}$ & \\
\hline $37 \mathrm{~S} / 33 \mathrm{E}-14 \mathrm{bcb}$ & North Borax Lake Group 1 & 17 & $42^{\circ} 19^{\prime} 49^{\prime \prime} 124^{\circ} 36^{\prime} 09^{\prime \prime}$ & 4,065 & $\begin{array}{l}3 / 20 / 91 \\
7 / 13 / 91 \\
4 / 01 / 92 \\
6 / 30 / 92 \\
9 / 09 / 92\end{array}$ & $\begin{array}{l}63.7 \\
40.9 \\
41.3 \\
38.8 \\
37.6\end{array}$ & $\begin{array}{l}2,400 \\
-- \\
2,360 \\
2,040 \\
1,990\end{array}$ & \\
\hline
\end{tabular}


Table 1. Records of selected springs in the Pueblo Valley, Oregon-Continued

\begin{tabular}{|c|c|c|c|c|c|c|c|c|}
\hline $\begin{array}{l}\text { Spring } \\
\text { location } \\
\text { number }\end{array}$ & $\begin{array}{l}\text { Spring } \\
\text { name }\end{array}$ & $\begin{array}{l}\text { Spring } \\
\text { identification } \\
\text { number }\end{array}$ & ' Latitude Longitude & $\begin{array}{c}\text { Altitude } \\
\text { (feet) }\end{array}$ & Date & $\begin{array}{c}\text { Temperature } \\
\text { (in degrees } \\
\text { (Celsius) }\end{array}$ & $\begin{array}{l}\text { Specific } \\
\text { conductance }\end{array}$ & Remarks \\
\hline $37 \mathrm{~S} / 33 \mathrm{E}-14 \mathrm{bcb}$ & North Borax Lake Group 1 & 18 & $42^{\circ} 19^{\prime} 49^{\prime \prime} 124^{\circ} 36^{\prime} 09^{\prime \prime}$ & 4,065 & $\begin{array}{l}3 / 20 / 91 \\
7 / 13 / 91 \\
4 / 01 / 92 \\
6 / 30 / 92 \\
9 / 09 / 92\end{array}$ & $\begin{array}{l}62.0 \\
34.7 \\
72.0 \\
71.1 \\
73.4\end{array}$ & $\begin{array}{l}2,400 \\
-- \\
2,000 \\
2,100 \\
2,110\end{array}$ & \\
\hline $37 \mathrm{~S} / 33 \mathrm{E}-14 \mathrm{bcb}$ & North Borax Lake Group 1 & 19 & $42^{\circ} 19^{\prime} 49^{\prime \prime} 124^{\circ} 36^{\prime} 09^{\prime \prime}$ & 4,065 & $\begin{array}{l}3 / 20 / 91 \\
7 / 13 / 91 \\
4 / 01 / 92 \\
6 / 30 / 92 \\
9 / 09 / 92\end{array}$ & $\begin{array}{l}59.5 \\
67.9 \\
67.7 \\
65.4 \\
67.2\end{array}$ & $\begin{array}{l}2,350 \\
-- \\
-- \\
2,070 \\
2,060\end{array}$ & \\
\hline $37 \mathrm{~S} / 33 \mathrm{E}-14 \mathrm{bcb}$ & North Borax Lake Group 1 & 21 & $42^{\circ} 19^{\prime} 49^{\prime \prime} 124^{\circ} 36^{\prime} 09^{\prime \prime}$ & 4,065 & $\begin{array}{l}3 / 20 / 91 \\
7 / 13 / 91 \\
4 / 01 / 92 \\
6 / 30 / 92 \\
9 / 09 / 92\end{array}$ & $\begin{array}{l}65.1 \\
67.9 \\
69.0 \\
68.7 \\
70.8\end{array}$ & $\begin{array}{l}2,370 \\
-- \\
2,110 \\
2,070 \\
2,070\end{array}$ & \\
\hline $37 \mathrm{~S} / 33 \mathrm{E}-14 \mathrm{bcb}$ & North Borax Lake Group 1 & 22 & $42^{\circ} 19^{\prime} 49^{\prime \prime} 124^{\circ} 36^{\prime} 09^{\prime \prime}$ & 4,065 & $\begin{array}{l}3 / 20 / 91 \\
7 / 13 / 91 \\
4 / 01 / 92 \\
6 / 30 / 92 \\
9 / 09 / 92\end{array}$ & $\begin{array}{l}71.0 \\
65.4 \\
72.9 \\
73.0 \\
73.6\end{array}$ & $\begin{array}{l}2,340 \\
-- \\
2,440 \\
2,130 \\
2,110\end{array}$ & \\
\hline $37 \mathrm{~S} / 33 \mathrm{E}-14 \mathrm{bcb}$ & North Borax Lake Group 1 & 23 & $42^{\circ} 19^{\prime} 49^{\prime \prime} 124^{\circ} 36^{\prime} 09^{\prime \prime}$ & 4,065 & $\begin{array}{l}3 / 20 / 91 \\
7 / 13 / 91 \\
4 / 01 / 92 \\
6 / 30 / 92 \\
9 / 09 / 92\end{array}$ & $\begin{array}{l}48.6 \\
44.8 \\
42.5 \\
45.3 \\
46.4\end{array}$ & $\begin{array}{l}2,270 \\
-- \\
2,360 \\
2,060 \\
1,970\end{array}$ & \\
\hline $37 \mathrm{~S} / 33 \mathrm{E}-14 \mathrm{bcb}$ & North Borax Lake Group 1 & 24 & $42^{\circ} 19^{\prime} 49^{\prime \prime} 124^{\circ} 36^{\prime} 09^{\prime \prime}$ & 4,065 & $\begin{array}{l}3 / 20 / 91 \\
7 / 13 / 91 \\
4 / 01 / 92 \\
6 / 30 / 92 \\
9 / 09 / 92\end{array}$ & $\begin{array}{l}53.0 \\
55.5 \\
69.3 \\
55.1 \\
68.7\end{array}$ & $\begin{array}{l}2,290 \\
-- \\
2,160 \\
2,050 \\
1,960\end{array}$ & \\
\hline $37 \mathrm{~S} / 33 \mathrm{E}-22 \mathrm{cda}$ & Salt Springs & 2 & $42^{\circ} 18^{\prime} 30^{\prime \prime} 124^{\circ} 36^{\prime} 53^{\prime \prime}$ & 4,068 & $\begin{array}{l}3 / 21 / 91 \\
4 / 02 / 92 \\
7 / 01 / 92 \\
9 / 09 / 92\end{array}$ & $\begin{array}{l}12.5 \\
10.5 \\
22.3 \\
25.0\end{array}$ & $\begin{array}{l}406 \\
443 \\
370 \\
353\end{array}$ & South \\
\hline $37 \mathrm{~S} / 33 \mathrm{E}-22 \mathrm{dbc}$ & Salt Springs & 1 & $42^{\circ} 18^{\prime} 45^{\prime \prime} 124^{\circ} 36^{\prime} 48^{\prime \prime}$ & 4,067 & $\begin{array}{l}3 / 21 / 91 \\
4 / 02 / 92 \\
7 / 01 / 92 \\
9 / 09 / 92\end{array}$ & $\begin{array}{l}17.4 \\
21.3 \\
23.6 \\
26.8\end{array}$ & $\begin{array}{l}407 \\
407 \\
350 \\
346\end{array}$ & North \\
\hline 37S/34E-6dba & 1 mile SW of Buckbrush & 1 & $42^{\circ} 21^{\prime} 15^{\prime \prime} 124^{\circ} 33^{\prime} 10^{\prime \prime}$ & 4,055 & $\begin{array}{l}4 / 02 / 92 \\
7 / 01 / 92 \\
9 / 10 / 92\end{array}$ & $\begin{array}{l}24.1 \\
16.9 \\
24.7\end{array}$ & $\begin{array}{l}327 \\
290 \\
249\end{array}$ & \\
\hline $37 \mathrm{~S} / 34 \mathrm{E}-6 \mathrm{dba}$ & 1 mile SW of Buckbrush & 2 & $42^{\circ} 21^{\prime} 15^{\prime \prime} 124^{\circ} 33^{\prime} 10^{\prime \prime}$ & 4,055 & $\begin{array}{l}4 / 02 / 92 \\
7 / 01 / 92 \\
9 / 09 / 92\end{array}$ & $\begin{array}{r}6.5 \\
17.3 \\
14.8\end{array}$ & $\begin{array}{l}327 \\
250 \\
321\end{array}$ & \\
\hline 37S/34E-6dba & 1 mile SW of Buckbrush & 3 & $42^{\circ} 21^{\prime} 15^{\prime \prime} 124^{\circ} 33^{\prime} 10^{\prime \prime}$ & 4,055 & $\begin{array}{l}7 / 01 / 92 \\
9 / 09 / 92\end{array}$ & $\begin{array}{l}16.9 \\
14.3\end{array}$ & $\begin{array}{l}303 \\
315\end{array}$ & \\
\hline 37S/34E-7bab & 1.5 miles SW of Buckbrush & 1 & $42^{\circ} 21^{\prime} 54^{\prime \prime} 124^{\circ} 33^{\prime} 34^{\prime \prime}$ & 4,040 & $\begin{array}{l}4 / 02 / 92 \\
7 / 01 / 92 \\
9 / 09 / 92\end{array}$ & $\begin{array}{l}12.6 \\
15.4 \\
13.2\end{array}$ & $\begin{array}{l}535 \\
480 \\
399\end{array}$ & \\
\hline
\end{tabular}


The water levels measured at the other four wells near Borax Lake were below land surface and were stable during the period of observation (table 2).

\section{Water Quality}

Limited water-quality data were collected as part of this study; however, three sets of samples were collected by Robert Mariner, USGS, Menlo Park, California. Analytical data from these samples is listed in table 3. Major ion and isotope analyses for the three samples were similar even though the samples were collected from a flowing well, a hot spring, and Borax Lake.

\section{MONITORING PLAN}

The focus of the proposed monitoring plan is to provide instrumentation for Borax Lake and surrounding springs and wells in order to begin collection of baseline data on discharge, water levels, water temperature, and specific conductance. Intensive water-quality data sampling and analysis will begin to provide information needed to establish baseline conditions for the Borax Lake area. The major elements of the monitoring plan to be considered are discussed in this section along with how specific types of data would be collected.

\section{Borax Lake}

\section{Inflow/Discharge}

During Phase I of this study, considerable effort was made to establish a method for measuring the rate of inflow of geothermal water into Borax Lake. Acoustic and electromagnetic velocity meters were used for data collection to help understand and interpret the rate of inflow and the variability in the flow rate. The primary question was whether an acoustic velocity meter, installed in the main orifice or vent, could be used to accurately measure inflow rate and variability in the inflow rate. On the basis of current knowledge about the diffuse nature of the inflow, the unsteady/ convective nature of the inflow, and particularly the abundant degassing in the vent area, it is unlikely an acoustic velocity meter could accurately measure the inflow to the lake.

An alternative to measuring inflow is to measure surface-water discharge from the lake; however, measurement of runoff is not equivalent to inflow. To estimate inflow from discharge, several components of discharge must be considered as shown in the following equation:

$$
\begin{aligned}
\text { Inflow }= & \text { surface runoff }+ \text { ground-water outflow } \\
& + \text { evaporation }- \text { precipitation. }
\end{aligned}
$$

It is difficult, however, to measure ground-water discharge and evaporation with sufficient accuracy to detect small changes in these components of discharge.

An alternative approach to measuring all components of discharge would be to consider that the flow system has relatively constant ground-water discharge and evaporation and then to measure surface-water runoff. Runoff could then be considered an indicator of (but not equivalent to) inflow into the lake and would also give an indication of the variability in the inflow and the change in inflow over a period of time.

The assumption that ground-water discharge remains constant is valid if the stage of the lake remains relatively constant and the shallow groundwater system is in equilibrium. The assumption that evaporation from the lake remains constant from year to year is probably reasonable, because the area of the lake, average temperature of air and water, solar energy input, and wind velocities will remain constant. In addition, the variability in evaporation is probably small with respect to the error associated with surface-water discharge measurements. Data would be collected on ground-water discharge and evaporation to support these assumptions.

Accurate measurement of surface-water discharge from the lake is impossible at the present time, because of current lake stage and the directions and modes of surface-water discharge taking place. The stage of the lake would have to be lowered to isolate or channel the discharge in order to accurately measure runoff from the lake. 
Table 2. Records of selected wells in the Pueblo Valley, Oregon

Well location number:

Refer to explanation and diagram of Well-Numbering System.

Latitude:

Latitude of spring in ${ }^{\circ}$, degrees; ', minutes; ", seconds.

Longitude:

Longitude of spring in ${ }^{\circ}$, degrees; ', minutes; ", seconds.

Altitude:

Altitude of land surface at well, in feet above mean sea level, estimated from topographic maps.

Depth of open interval:

Depth, in feet below land surface, of open, perforated or screened intervals.

\begin{tabular}{|c|c|c|c|c|c|c|c|c|c|}
\hline \multirow{2}{*}{$\begin{array}{c}\text { Well } \\
\text { location } \\
\text { number }\end{array}$} & \multirow[b]{2}{*}{ Owner } & \multirow{2}{*}{$\begin{array}{l}\text { Date } \\
\text { drilled }\end{array}$} & \multirow[b]{2}{*}{ Latitude } & \multirow[b]{2}{*}{ Longitude } & \multirow[b]{2}{*}{ Altitude } & \multirow{2}{*}{$\begin{array}{l}\text { Depth } \\
\text { of well } \\
\text { (feet) }\end{array}$} & \multicolumn{2}{|c|}{$\begin{array}{c}\text { Depth } \\
\text { of open interval } \\
\text { (feet) }\end{array}$} & \multirow{2}{*}{$\begin{array}{c}\text { Well } \\
\text { diameter } \\
\text { (inches) }\end{array}$} \\
\hline & & & & & & & Top & Bottom & \\
\hline $37 \mathrm{~S} / 33 \mathrm{E}-9 \mathrm{acb}$ & Kurtz & 1963 & $42^{\circ} 20^{\prime} 45^{\prime \prime}$ & $124^{\circ} 38^{\prime} 00^{\prime \prime}$ & 4,056 & 171.0 & 168.0 & 171.0 & 8.0 \\
\hline 37S/33E-9acc & $\begin{array}{l}\text { Humbolt Land } \\
\text { and Livestock }\end{array}$ & 1986 & $42^{\circ} 20^{\prime} 33^{\prime \prime}$ & $124^{\circ} 38^{\prime} 00^{\prime \prime}$ & 4,057 & 171.7 & 171.2 & 171.7 & 12.0 \\
\hline 37S/33E-10dcd & $\begin{array}{l}\text { Bureau of Land } \\
\text { Management }\end{array}$ & 1981 & $42^{\circ} 20^{\prime} 10^{\prime \prime}$ & $124^{\circ} 36^{\prime} 40^{\prime \prime}$ & 4,028 & 208.0 & 188.0 & 208.0 & 8.0 \\
\hline $37 \mathrm{~S} / 33 \mathrm{E}-14 \mathrm{abc}$ & $\begin{array}{r}\text { Bureau of Land } \\
\text { Management }\end{array}$ & 1959 & $42^{\circ} 19^{\prime} 57^{\prime \prime}$ & $124^{\circ} 35^{\prime} 38^{\prime \prime}$ & 4,045 & 150.0 & -- & -- & 8.0 \\
\hline 37S/33E-17aba & $\begin{array}{r}\text { Bureau of Land } \\
\text { Management }\end{array}$ & -- & $42^{\circ} 20^{\prime} 01^{\prime \prime}$ & $124^{\circ} 38^{\prime} 59^{\prime \prime}$ & 4,133 & 74.4 & -- & -- & 6.0 \\
\hline 37S/33E-31bad & $\begin{array}{r}\text { Bureau of Land } \\
\text { Management }\end{array}$ & 1958 & $42^{\circ} 17^{\prime} 17^{\prime \prime}$ & $124^{\circ} 33^{\prime} 24^{\prime \prime}$ & 4,081 & 61.0 & 58.0 & 61.0 & 6.0 \\
\hline
\end{tabular}

The most accurate measurement of surface-water runoff (within 5 percent) from the lake can be made by diverting the flow from the lake into the old existing channel that flows to the dry Lower Borax Lake Reservoir. Vegetation in the existing channel would have to be removed to allow flow from Borax Lake to Lower Borax Lake Reservoir. In addition, the stage of Borax Lake could be lowered approximately 1 foot to eliminate runoff to other channels and seepage around the rim of the lake. A weir with a continuous recording gage could be installed in the channel approximately
200 feet west of Borax Lake. Another continuous record gage could be installed on the lake to record lake stage.

A second, less accurate method of measuring flow is to install multiple weirs at multiple channels (possibly as few as 4 or 5 of them) around the lake. However, the lake stage would still have to be lowered approximately 6 inches to eliminate seepage of water through grassy areas around the lake. The accuracy of this approach would be significantly less (about 25 percent), and continuous recorders may be difficult to install. 


\begin{tabular}{|c|c|c|c|c|c|c|c|c|}
\hline \multicolumn{2}{|c|}{$\begin{array}{l}\text { Well diameter: } \\
\text { Test method: } \\
\text { Yield: } \\
\text { Water level: } \\
\text { Specific conductance: }\end{array}$} & \multicolumn{4}{|c|}{$\begin{array}{l}\text { Nominal inside diameter of well casing at land surface. } \\
\text { B, bailed; F, flowing. } \\
\text { Well yield in gallons per minute (gal/min). } \\
\text { Water levels measured by U.S. Geological Survey Personnel. } \\
\text { In microsiemens per centimeter at } 25 \text { degrees Celsius.. . }\end{array}$} & \multirow[b]{3}{*}{$\begin{array}{l}\text { Temperature } \\
\text { (Degrees C) }\end{array}$} & \multirow[b]{3}{*}{$\begin{array}{c}\text { Specific } \\
\text { conductance }\end{array}$} & \multirow[b]{3}{*}{ Remarks } \\
\hline \multicolumn{4}{|c|}{ Well performance } & \multicolumn{2}{|c|}{ Water level } & & & \\
\hline $\begin{array}{l}\text { Test } \\
\text { method }\end{array}$ & $\begin{array}{c}\text { Yield } \\
\text { (gal } / \mathrm{min})\end{array}$ & $\begin{array}{l}\text { Drawdown } \\
\text { (feet) }\end{array}$ & $\begin{array}{l}\text { Test period } \\
\text { (hours) }\end{array}$ & $\begin{array}{l}\text { Feet below } \\
\text { datum }\end{array}$ & Date & & & \\
\hline- & 600.0 & 12.0 & 72.0 & 4.50 & $8 / 11 / 79$ & -- & -- & \\
\hline- & -- & -- & -- & 3.96 & $3 / 21 / 91$ & -- & -- & \\
\hline- & -- & -- & -- & 4.14 & $4 / 01 / 92$ & -- & -- & \\
\hline- & -- & -- & -- & 4.24 & $6 / 30 / 92$ & -- & -- & \\
\hline- & -- & -- & -- & 4.41 & 9/09/92 & -- & -- & \\
\hline B & 50.0 & 2.0 & 1.0 & 13.00 & $11 / 20 / 86$ & 36 & -- & $\begin{array}{l}\text { Sounded to } 117.7 \text { feet } \\
\text { on } 3 / 21 / 91\end{array}$ \\
\hline- & -- & -- & -- & 7.20 & $3 / 21 / 91$ & -- & -- & \\
\hline - & -- & -- & -- & 7.88 & $4 / 01 / 92$ & -- & -- & \\
\hline - & -- & -- & -- & 7.90 & $6 / 30 / 92$ & -- & -- & \\
\hline- & -- & -- & -- & 8.02 & $9 / 09 / 92$ & -- & -- & \\
\hline $\mathrm{F}$ & 55.0 & -- & -- & -- & $11 / 13 / 81$ & 16 & -- & \\
\hline $\mathrm{F}$ & 30.0 & -- & -- & -- & $4 / 01 / 92$ & 16 & 281 & \\
\hline $\mathrm{F}$ & 30.0 & -- & -- & -- & $6 / 30 / 92$ & 16 & 250 & \\
\hline $\mathrm{F}$ & 28.0 & -- & -- & -- & $9 / 09 / 92$ & 16 & 279 & \\
\hline - & -- & -- & -- & -- & $7 / 11 / 92$ & 58 & 2,140 & $\begin{array}{l}\text { Sounded to } 25.0 \text { feet } \\
\text { on } 7 / 11 / 91\end{array}$ \\
\hline $\mathrm{F}$ & 17.0 & -- & -- & -- & $4 / 02 / 92$ & 56 & 2,097 & \\
\hline $\mathrm{F}$ & 25.0 & -- & -- & -- & $6 / 30 / 92$ & 58 & 1,800 & \\
\hline $\mathrm{F}$ & 18.0 & -- & -- & -- & $9 / 09 / 92$ & 58 & 1,798 & \\
\hline- & -- & -- & -- & 70.23 & $3 / 21 / 91$ & -- & -- & \\
\hline B & 30.0 & 11.0 & 1.0 & 24.00 & $4 / 09 / 58$ & -- & -- & \\
\hline- & -- & -- & -- & 22.38 & $8 / 10 / 79$ & -- & -- & \\
\hline - & -- & -- & -- & 21.48 & $4 / 11 / 91$ & -- & -- & \\
\hline- & -- & -- & -- & 21.45 & $4 / 01 / 92$ & -- & -- & \\
\hline- & -- & -- & -- & 21.46 & $7 / 01 / 92$ & -- & -- & \\
\hline - & -- & -- & -- & 21.51 & $9 / 10 / 92$ & -- & -- & \\
\hline
\end{tabular}

As with the first approach, a stage recorder would be installed on the lake to record lake stage. Single and multiple weirs would be subject to freezing during winter months, although the single weir would be less likely to freeze because of the greater flow.

Another possible method, but less desirable, would employ some type of barrier around the lake that would actually allow lake stage to remain at its current level and eliminate all runoff except to the existing channel to Lower Borax Lake Reservoir. This barrier would require extensive damming around the perimeter of the lake but would maintain the lake level. Natural building of the lake rim would cease as a result of this damming.

\section{Lake Stage}

A gage would be installed on the lake to monitor stage. These data would be used to analyze and interpret the inflow/discharge into and from the lake.

The gage would be installed using standard USGS procedures and probably would be located on the 
Table 3. Results of chemical analyses of water samples collected from the Borax Lake area, Oregon $\left[\mathrm{SiO}_{2}\right.$, silica; $\mathrm{B}$, boron; $\mathrm{Ca}$, calcium;, $\mathrm{Mg}$, magnesium; $\mathrm{Li}$, lithium; $\mathrm{Na}$, sodium; $\mathrm{K}$, potassium; $\mathrm{HCO}_{3}$, bicarbonate; $\mathrm{CaCO}_{3}$, calcium carbonate; $\mathrm{SO}_{4}$, sulfate; $\mathrm{Cl}$, chloride; $\mathrm{O}^{18}$, oxygen- 18 ; $\delta$, delta; per mil, per milliliter]

\begin{tabular}{|c|c|c|c|c|c|c|c|c|c|c|c|c|c|c|c|}
\hline $\begin{array}{c}\text { Sample } \\
\text { identification }\end{array}$ & pH & $\begin{array}{l}\text { Temperature } \\
\text { (in degrees } \\
\text { Celsius) }\end{array}$ & $\mathrm{SiO}_{2}$ & B & Ca & Mg & $\underset{--M i l l i}{\mathbf{L i}}$ & $\underset{\text { Irams }}{\mathrm{Na}}$ & $\begin{array}{c}\text { K } \\
\text { per L }\end{array}$ & $\frac{\text { Alkali }}{\mathrm{HCO}_{3}}$ & $\frac{\text { nity in }}{\mathrm{CaCO}_{3}}$ & $\mathrm{SO}_{4}$ & Cl & $\begin{array}{c}\delta \\
\text { Deuterium } \\
\text { (per mil) }\end{array}$ & $\begin{array}{c}\delta \\
0^{18} \\
\text { (per mil) }\end{array}$ \\
\hline Borax Lake vent & 7.44 & 31 & 194 & 16 & 15 & 0.4 & 0.57 & 515 & 28 & 430 & 353 & 340 & 285 & -117 & -12.0 \\
\hline Well 37S/33E-14abc & 6.56 & 58 & 222 & 14 & 15 & 1.2 & 0.47 & 420 & 25 & 398 & 326 & 275 & 240 & -129 & -14.8 \\
\hline $\begin{array}{l}\text { Spring \#13- } \\
\text { North Borax Lake } \\
\text { Spring Group } 4\end{array}$ & 7.62 & 35 & 160 & 15 & 16 & 0.3 & 0.51 & 450 & 24 & 420 & 344 & 295 & 250 & -124 & -13.9 \\
\hline
\end{tabular}

western edge of the lake. Ideally, the same gage house could be used for the weir gage and the lake gage. Both gages could utilize data loggers and transducers. All data-collection activities implemented could provide real-time accessibility by using telephone lines or satellite-transmission systems.

\section{Evaporation}

Evaporation from Borax Lake could not be estimated using standard techniques. Evaporation rates determined by conventional methods for eastern Oregon would not apply, because high temperatures of water in the lake occur during the entire year. Evaporation rates may be high in the winter as well as in the summer months.

Data collection to estimate evaporation probably will require installation of an evaporation pan and an instrument raft to measure wind velocities on the lake, as well as water and air temperatures. Some form of energy-budget analysis could be used to estimate evaporation; however, determining the actual method of analysis is beyond the scope of this report. In addition to collecting data on the lake, a weather station would also be operated to collect precipitation, solar radiation, humidity, and barometric pressure data. Currently, the BLM is collecting these data.

\section{Water Temperature and Specific Conductance}

Water temperature and specific conductance would be monitored in Borax Lake on a continuous basis. A minimum of two measurement sites would be established in the center of the vent area. One site would be located close to the bottom of the vent at a depth of approximately 90 feet, and the second site would be located at a depth of about 10 feet. A deep temperature probe would be placed 1 to 2 feet above the bottom of the vent to facilitate measuring average conditions instead of absolute vent temperatures. Other probes may be installed in an attempt to measure inflowing temperatures; however, this may be difficult because of the multiple openings and the possibility that some openings may become inactive while others become active. To minimize the effects of solar radiation on water temperature that might occur in shallow parts of the lake, a shallow temperature probe should be placed above the vent to accurately measure the characteristics of inflowing vent water.

The location of these data-collection sites at the bottom of Borax Lake would be fixed by using substantial anchoring devices, such as 100-pound weights or anchors. The location of the site must be relocatable so that the probes could be placed at the same position after maintenance.

Probe maintenance would be done on a bimonthly or more frequent basis, and probes would be employed in duplicate because of the severe conditions in Borax Lake. With this approach, a malfunctioning probe can be diagnosed and replaced in a timely manner with no loss of data.

The probes would be interfaced with data loggers and possibly housed in the same gage house as the stage gages. Continuous monitoring of other field water-quality parameters, such as $\mathrm{pH}$ and dissolved oxygen, also would be evaluated. 


\section{Water-Quality Sampling and Analysis}

Geothermal development or production of geothermal fluids could affect discharge from the geothermal system as well as the chemical composition of the discharging water. The following discussion describes a plan for collecting water samples in the Borax Lake area for chemical analysis.

Water-quality samples would be collected from Borax Lake using standard USGS procedures. Conditions in the lake may require that sampling methods be devised to ensure that samples are always collected from the same location for comparison purposes, although samples would be taken at various depths. Chemical constituents proposed for analyses are listed in the Appendix.

Physical parameters and chemical constituents were selected on the basis of "Guidelines for acquiring environmental baseline data on Federal geothermal leases," (U.S. Department of Interior, 1977). Oxygen and deuterium isotope concentrations were included because of their usefulness in identifying sources of water.

The schedule for sampling the Borax Lake study area would be designed to evaluate variability in constituents over periods of days, weeks, and years. Also, samples would be collected at various depths. A suggested schedule for sampling is as follows. Suggested sampling schedule for Borax Lake area monitoring:

\begin{tabular}{|c|c|c|c|c|}
\hline \multirow[b]{2}{*}{ Date } & \multicolumn{3}{|c|}{$\begin{array}{c}\text { Number } \\
\text { of samples } \\
\text { per site }\end{array}$} & \multirow{2}{*}{$\begin{array}{c}\text { Estimated } \\
\text { number of } \\
\text { sample sets } \\
\text { per trip }\end{array}$} \\
\hline & Lake(4)* & Springs(2)* & Wells(2)* & \\
\hline October & 3 & 3 & 3 & 24 \\
\hline November & 1 & 1 & 1 & 8 \\
\hline December & 1 & 1 & 1 & 8 \\
\hline January & 1 & 1 & 1 & 8 \\
\hline February & 1 & 1 & 1 & 8 \\
\hline March & 1 & 1 & 1 & 8 \\
\hline \multicolumn{5}{|l|}{ April } \\
\hline \multicolumn{5}{|l|}{ May } \\
\hline June & 1 & 1 & 1 & 8 \\
\hline \multicolumn{5}{|l|}{ July } \\
\hline \multicolumn{5}{|l|}{ August } \\
\hline September & 1 & 1 & 1 & 8 \\
\hline
\end{tabular}

* The number in parentheses indicates the number of sampling sites.
October sampling would be for field parameters and major chemical constituents, with the exception of one sample set for each site that would include all chemical constituents described in the Appendix.

After monitoring for 1 to 2 years with the type of sampling schedule suggested, variations in parameters could be evaluated and the sampling schedule modified as needed. If the variance of the data for selected parameters is small, the sampling frequency and monitoring costs could be reduced.

\section{Shallow Ground Water Adjacent to Borax Lake}

\section{Ground-Water Levels}

Surface-water discharge from the lake would be monitored to detect any significant changes in inflow to Borax Lake. The ability to use discharge as an indicator of inflow depends on other components of the water budget for the lake. One component is the shallow ground-water discharge from the lake, which should remain constant if the stage of the lake is held relatively constant.

Shallow ground-water levels near Borax Lake could be monitored using shallow drive-point piezometers. These piezometers would be used to measure shallow water levels and to evaluate whether or not the shallow ground-water system is in equilibrium.

Piezometers would be placed along flow lines, and at least two sets of three piezometers would be installed in a radial pattern out from the lake. Each monitoring set would have a piezometer at approximately 10-, 20-, and 30-foot distances from the lake. Water-level measurements would be made on a monthly basis in these piezometers; one or two piezometers would be monitored on a continuous basis by using transducers and data loggers.

This water-level data would be useful to determine if the shallow ground-water system is in equilibrium and also to determine gradients near the lake. The gradient data and some simple slug-test data for calculation of hydraulic conductivity could allow an approximate estimation of shallow ground water discharged from the lake. 


\section{North Borax Lake Spring Group 1}

\section{Water Temperature and Specific Conductance}

Water temperature and specific conductance would be monitored in at least one hot spring and possibly two hot springs in the closest group of springs located north of the lake. These springs may also be an important indicator of variations in temperatures and chemistry in the local geothermal system. Measurement of discharge at one of the springs is another possibility.

Monitoring in the springs would be done by using an approach similar to that used in Borax Lake. Data loggers could be housed in a gage house at the springs, and the resulting data also would be available on a realtime basis.

\section{Water-Quality Sampling and Analysis}

Springs would be sampled according to the suggested schedule given in the "Borax Lake, WaterQuality Sampling and Analysis" section of this report. The samples would be analyzed for the constituents listed in the Appendix. The only exception would be the October samples, for which only one set of samples would be analyzed for the complete set of chemical constituents. All other samples collected during the October sampling would be analyzed for major chemical constituents only.

\section{Wells}

\section{Construction}

Well 37S/33E-14abc is located approximately one-half mile northeast of Borax Lake. The well was apparently drilled as part of a sodium-prospecting project during the late 1950's and early 1960's. The well flows at a rate of approximately 50 gallons per minute and water temperature has been measured at $58^{\circ} \mathrm{C}$. The depth of the well was sounded at 25 feet; however, there is some question about the construction of the well. This well may provide a good site for collection of baseline information, but it must be reconditioned so that the open interval of the well can be verified. The wellhead would also require modification to allow the well to be shut in for measurement of static water levels; however, accurate flow measurements also could be made.

Verification of construction and modification of the wellhead would require the hiring of contractors. Drilling, down-hole camera, and geophysical equipment may be needed to prepare the well for monitoring. In the event that the well cannot be properly reconditioned for monitoring, the well could be sealed and abandoned to prevent human-caused discharge of geothermal water.

Well 37S/33E-10dcd is approximately 1 mile northwest of Borax Lake and also would be a useful site for data collection.

\section{Water Levels, Temperature, and Discharge}

If wells 37S/33E-14abc and 37S/33E-10dcd can be shut in, water levels and temperatures would be monitored on a continuous basis. In addition, accurate discharge measurements would be made with the same frequency as water-quality sampling. If for some reason it is not possible to shut the wells in, only discharge and temperature would be measured. Specific conductance also may be monitored on a continuous basis as an indicator of changes in water chemistry with time.

\section{Water-Quality Sampling and Analysis}

The wells (37S/33E-14abc and 37S/33E-10dcd) would be sampled by using the schedule in the "Borax Lake, Water-Quality Sampling and Analysis" section of this report. Both wells are flowing wells; therefore, pumps would not be needed. The wells would be allowed to flow until three well-bore volumes of water have been removed from the well to assure that formation water is being sampled.

\section{Deep Geothermal Well(s)}

\section{Review Available Geothermal Well, Geologic Map, and Geophysical Data}

As part of Phase II of the Borax Lake area study, collection of hydrologic data from wells located between the proposed geothermal development and environmentally sensitive areas would be necessary. 
These wells could provide an "early warning" datacollection network, so that appropriate actions could be taken before geothermal development activities would affect sensitive areas. A review of available data from existing and abandoned geothermal wells, geologic maps, and geophysical information is needed to determine if existing wells are adequate for collection of data or if new wells should be drilled for monitoring. This review was suggested in the Phase II work plan. If geothermal development in the Borax Lake area occurs, the use of monitoring wells should be evaluated at that time.

There are several observation and exploration wells just south of Borax Lake that, if still accessible and completed in appropriate zones, could be used for monitoring purposes.

Geologic and geophysical data are available for the Pueblo Valley near Borax Lake. Much of these data are, however, proprietary to companies that collected the information. This information and possibly additional information may have to be reviewed to determine the feasibility of using existing or new wells to monitor ground-water conditions between Borax Lake and areas of geothermal development. This review would require cooperation between Federal agencies and private-exploration companies.

When the existing data are reviewed, it may become apparent that the system is too complex to locate monitoring wells properly, or that drilling deep wells near Borax Lake could adversely affect the geothermal system. It may also be determined that the most appropriate way to monitor the thermal aquifer or upflow system to Borax Lake is to install a shallow well near North Borax Lake Spring Group 1 to evaluate changes in thermal-aquifer pressures.

\section{SELECTED REFERENCES}

Garber, M.S., and Koopman, F.C., 1968, Methods of measuring water levels in deep wells: U.S. Geological Survey Techniques of WaterResources Investigations, book 8, chap. A1, 23 p.

Gonthier, J.B., 1985, A description of aquifer units in eastern Oregon: U.S. Geological Survey WaterResources Investigations Report 84-4095, 39 p., 4 sheets.

Reed, J.E., Bedinger, M.S., and Gonthier, J.B., 1984, Maps showing ground-water units and number of large capacity wells, Basin and Range Province, Oregon: U.S. Geological Survey Water-Resources Investigations Report 83-4120-A, 4 p., 1 sheet, scale 1:500,000.

Reed, J.E., Bedinger, M.S., Gonthier, J.B., Langer, W.H., McFarland, W.D., and Mulvihill, D.A., 1984, Maps showing ground-water levels, springs, and depth to ground water, Basin and Range Province, Oregon: U.S. Geological Survey Water-Resources Investigations Report 83-4120-B, 5 p., 1 sheet, scale 1:500,000.

Sifford, Alex, Beale, Kasi, 1991, Economic impacts of geothermal development in Harney County, Oregon, prepared for the Bonneville Power Administration by the Oregon Department of Energy under agreement no. DE-BI79-90BP07129: Salem, Oregon, 31 p.

Thompson, T.H., Chappel, Richard, Gonthier, J.B., and McFarland, W.D., 1984, Maps showing distribution of dissolved solids and dominant chemical type in ground water, Basin and Range Province, Oregon: U.S. Geological Survey Water-Resources Investigation Report 83-4120-C, 5 p., 1 sheet, scale 1:500,000.

Townley, P.J., Soja, C.M., Sidle, W.C., 1980, Groundwater data for Riley and Andrews Resource Areas, Southeastern Oregon: U.S. Geological Survey Open-File Report 80-419, 32 p.

U.S. Department of Interior, 1977, Guidelines for acquiring environmental baseline data on Federal geothermal leases: Menlo Park, California, Geothermal Environmental Advisory Panel, 26 p. 

APPENDIX 


\section{APPENDIX}

\section{Physical parameters, chemical constituents, and isotopes for monitoring sites.}

[Appendix includes analytical methods and detection limits used during laboratory analyses.]

A. Field parameters

(1) $\mathrm{pH}$, alkalinity, temperature, conductivity

(2) dissolved oxygen, when feasible (for instance, dissolved oxygen is not meaningful when samples are obtained from wells equipped with air-jet pumps)

B. Major chemistry (dissolved unless otherwise stated) and physical parameters (concentration or unit values listed by each parameter are the minimum detection levels that will be used)

(1) major ions:

$\mathrm{Ca}$, atomic absorption, $0.1 \mathrm{mg} / \mathrm{L}$

$\mathrm{Mg}$, atomic absorption, $0.1 \mathrm{mg} / \mathrm{L}$

$\mathrm{Na}$, atomic absorption, $0.1 \mathrm{mg} / \mathrm{L}$

$\mathrm{K}$, atomic absorption, $0.1 \mathrm{mg} / \mathrm{L}$

$\mathrm{HCO}_{3}$, titration, $1 \mathrm{mg} / \mathrm{L}$

$\mathrm{Cl}$, ion chromatography, $1 \mathrm{mg} / \mathrm{L}$

$\mathrm{SO}_{4}$, ion chromatography, $1 \mathrm{mg} / \mathrm{L}$

$\mathrm{F}$, ion chromatography, $10 \mu \mathrm{g} / \mathrm{L}$

(2) minor constituents:

$\mathrm{SiO}_{2}$, colorimetry, molybdate blue, $0.1 \mathrm{mg} / \mathrm{L}$

A1, atomic emission, DG plasma, $10 \mu \mathrm{g} / \mathrm{L}$

$\mathrm{Fe}$, atomic absorption, $10 \mu \mathrm{g} / \mathrm{L}$

$\mathrm{Mn}$, atomic absorption, $10 \mu \mathrm{g} / \mathrm{L}$

(3) nutrients:

total $\mathrm{P}$, colorimetry, $10 \mu \mathrm{g} / \mathrm{L}$

ortho $\mathrm{P}$, colorimetry, $10 \mu \mathrm{g} / \mathrm{L}$

$\mathrm{NO}_{2}+\mathrm{NO}_{3}$, colorimetry, $0.1 \mathrm{mg} / \mathrm{L}$

$\mathrm{NH}_{4}$, colorimetry, $0.01 \mathrm{mg} / \mathrm{L}$

(4) dissolved solids: residue on evaporation, $1 \mathrm{mg} / \mathrm{L}$

(5) turbidity: nephelometry,

0.1 nephelometric turbidity units

C. Isotopes (dissolved):

(1) oxygen-18/oxygen-16, mass spectrometry, $+/-0.15 \mathrm{o} / \mathrm{oo}$

(2) deuterium/protium, mass spectrometry, $+/-1.5 \mathrm{o} / \mathrm{oo}$
D. Trace elements (dissolved):

(1) As, atomic absorption, $1 \mu \mathrm{g} / \mathrm{L}$

(2) $\mathrm{Ag}$, atomic absorption, graphite furnace, $1 \mu \mathrm{g} / \mathrm{L}$

(3) $\mathrm{B}$, atomic emission, DC plasma, $10 \mu \mathrm{g} / \mathrm{L}$

(4) $\mathrm{Ba}$, atomic absorption, $100 \mu \mathrm{g} / \mathrm{L}$

(5) $\mathrm{Cd}$, atomic absorption, $10 \mu \mathrm{g} / \mathrm{L}$

(6) $\mathrm{Cr}, \mathrm{DC}$ plasma, $1 \mu \mathrm{g} / \mathrm{L}$

(7) $\mathrm{Cu}$, atomic absorption, $10 \mu \mathrm{g} / \mathrm{L}$

(8) $\mathrm{Hg}$, atomic absorption, flameless, $0.1 \mu \mathrm{g} / \mathrm{L}$

(9) Li, atomic absorption, $10 \mu \mathrm{g} / \mathrm{L}$

(10) Mo, atomic absorption, $1 \mu \mathrm{g} / \mathrm{L}$

(11) $\mathrm{Pb}$, atomic absorption, graphite furnace, $1 \mu \mathrm{g} / \mathrm{L}$

(12) Se, atomic absorption, $1 \mu \mathrm{g} / \mathrm{L}$

(13) $\mathrm{Sr}$, atomic absorption, $10 \mu \mathrm{g} / \mathrm{L}$

(14) $\mathrm{Zn}$, atomic absorption, $10 \mu \mathrm{g} / \mathrm{L}$

E. Dissolved gases

(1) $\mathrm{CO}_{2}$, calibrated from alkalinity titration

(2) $\mathrm{H}_{2} \mathrm{~S}$, calculated from total recoverable sulfide; total recoverable sulfide determined by iodometric titrimetry with detection limit of 0.5 $\mathrm{mg} / \mathrm{L}$ as $\mathrm{S}$

(3) $\mathrm{NH}_{3}$, calculated from ammonium ion concentration

F. Radon-222 (dissolved): liquid scintillation, 70 pCi/L

G. Gross radioactivity (dissolved): gross alpha, residue proc., $0.4 \mu \mathrm{g} / \mathrm{L}(\mathrm{U}), 0.4 \mathrm{pCi} / \mathrm{L}$ (Th-230) gross beta, residue proc., 0.4 pCi/L (Sr-90/Y-90, Cs-137)

H. Vertical profiles:

(1) $\mathrm{pH}$

(2) temperature

(3) conductivity

(4) dissolved oxygen

I. Continuous monitoring: conductivity and temperature 